\title{
Environmental and Social Risk, Adaptation, and Equity Value
}

\author{
Curtis A. Farnsel * \\ Department of Accounting \\ University of Dayton \\ cfarnsel1@udayton.edu

\section{PRELIMINARY - NOT FOR PUBLIC DISTRIBUTION \\ PLEASE DO NOT CITE, SHARE OR DISTRIBUTE COMMENTS WELCOME}

\begin{abstract}
This study investigates the impact of environmental and social (E\&S) risks on firm value. Firm value is expected to be a function of current earnings to the extent current earnings reflect cash flows that are expected to recur in future periods ("recursion value"). However, to the extent a firm may be forced to modify its future operating processes, its current earnings are less likely to reflect future cash flows. Instead, firm value is expected to be a function of the net assets in place that can be used to generate an alternative stream of cash flows ("adaptation value"). I find that when $\mathrm{E} \& \mathrm{~S}$ risks are present, there is a partial shift from recursion value to adaptation value (i.e., the association between firm value and current earnings is lower, while the association between firm value and book value is higher). These results are consistent with institutional theory, which suggests that firms with poor E\&S performance face pressure from stakeholders and society at large to adapt or terminate their current operations. Further, I find that the partial shift to adaptation value in the presence of E\&S risk is stronger for firms with high asset tangibility, consistent with tangible assets being more adaptable than intangible assets. By demonstrating the link between E\&S risk and adaptation value, this study supports the recent practitioner focus on corporate social responsibility failures as a risk to business continuity.
\end{abstract}

* Department of Accounting, Miriam Hall 410, 300 College Park, Dayton, OH 45469, email: cfarnsel1@udayton.edu phone: 1-937-229-4184 


\section{INTRODUCTION}

Practitioners and academics have increased their focus on corporate social responsibility (CSR) in recent years, as instances of environmental and social (E\&S) failures continue to become more common and significant. ${ }^{1}$ For example, many prominent companies have recently been pressured to adapt otherwise profitable operations (e.g., Facebook, Dicks Sporting Goods, Ikea, etc.). ${ }^{2}$ However, the literature provides incomplete and inconclusive evidence on how such risks affect current firm value (Joshi and Li 2016). Using adaptation theory from Burgstahler and Dichev (1997), I examine how E\&S risks affect the relative value relevance of earnings and book value.

Burgstahler and Dichev (1997) suggest that firm value is expected to be a function of current earnings to the extent those earnings reflect cash flows that are expected to recur in future periods ("recursion value"). However, to the extent that a firm may be forced to modify its current operations, its current earnings are less likely to reflect future cash flows. In this case, firm value is expected to be a function of the net assets in place that can be used to generate an alternative stream of cash flows ("adaptation value"). Because at any point in time a firm has the option to either continue or adapt its current operations, firm value is a convex function of recursion value and adaptation value with the relative weights depending on the expectations that the earnings generating process will be modified. Based on institutional theory, which suggests firms failing

\footnotetext{
${ }^{1}$ The "environmental and social risk" terminology used throughout is nearly synonymous with the corporate social responsibility terminology used more broadly in the academic literature. For this study, I purposefully choose the terminology "environmental and social risk" to maintain consistency with the relevant practitioner guidance.

${ }^{2}$ A few of the more prominent examples include Facebook, Dicks Sporting Goods, and Ikea. Following user privacy concerns, Facebook is adapting its business model to collect less user data and reduce targeted advertising. In response to mounting public pressure for gun control, Dicks Sporting Goods instituted restrictive firearm sales policies. Ikea is phasing out all single use plastic items from its product offerings because of growing concern over plastic pollution.
} 
to meet societal expectations will be forced to adapt their operating processes, I predict $\mathrm{E} \& \mathrm{~S}$ risks will cause a partial shift from recursion value (i.e., earnings) to adaptation value (i.e., book value).

To test whether E\&S risks are reflected in firm value consistent with adaptation theory, I obtain a sample of 24,775 firm-year observations which have been rated for CSR performance by MSCI KLD Analytics (KLD). I classify firm-years as facing E\&S risk when the firm-year has more environmental and social attributes rated as concerns than as strengths. Using both an $R^{2}$ decomposition technique and an examination of regression coefficients, I investigate whether there is a partial shift toward adaptation value when E\&S risk is present. Results of both tests support my predictions that recursion value (adaptation value) has a weaker (stronger) association with firm value when E\&S risk is present. Further, I find that the partial shift to adaptation value is stronger for firms with high asset tangibility. This result is consistent with tangible assets having greater adaptability than intangible assets.

I conduct several additional tests to strengthen the primary conclusions. First, I present evidence for the theory underlying my predictions by showing that results vary predictably with firm financial performance. The partial shift to adaptation value is more pronounced for firms with strong financial performance consistent with E\&S risk increasing the perceived likelihood of adaptation in otherwise well performing firms. Next, I present evidence that my results are not driven by construct measurement choices. Using alternate proxies for adaptation value and E\&S risk, I present results comparable to those of the primary analysis. Further, results hold when disaggregating the E\&S risk measure into its major components indicating that results are not driven by one single component of E\&S performance. Finally, I present evidence that my results are not sensitive to sample selection considerations such as a changing sample composition over time and the inclusion of neutral CSR firms. 
This study makes several important contributions to an emerging literature on firm value effects of CSR. ${ }^{3}$ First, this study broadens prior research on the role of adaptation in equity valuation. Prior research shows that the relative importance of earnings and book value for valuation depend on firm financial performance (Burgstahler and Dichev 1997; Barth, Beaver, and Landsman 1998; Collins, Pincus, and Xie 1999). I show that the relative importance of earnings and book value also depends on firm nonfinancial performance (i.e., environmental and social performance). Second, this study answers the recent call for research on the valuation implications of CSR (Hales, Matsumura, Moser, and Payne 2016; Joshi and Li 2016). Existing research generally links CSR issues directly to firm value. For example, various measures of firm level pollution have been found to have negative coefficients in firm valuation models (Clarkson, Li, and Richardson 2004; Matsumura, Prakash, and Vera-Munoz 2014). This study introduces adaptation value as a channel through which CSR issues are reflected in firm value.

Further, this study offers timely, practical implications. In February 2018, the Committee of Sponsoring Organizations of the Treadway Commission (COSO) released guidance on responding to E\&S risks. ${ }^{4}$ Major accounting firms have echoed the need for an increased focus on E\&S issues (EY 2011; Deloitte 2017). The consensus among practitioners is that E\&S risks can influence profitability and survival prospects. This study motivates compliance with the new COSO guidance by presenting empirical evidence that firms which fail to address E\&S concerns are valued closer to adaptation value. Additionally, unanswered questions have been raised as to whether the FASB should establish required disclosures about E\&S issues (Siegel 2017). Thus

\footnotetext{
${ }^{3}$ Malik (2015) offers a review of over 60 existing studies in accounting, finance, and management journals that have examined various value-enhancing capabilities of CSR.

${ }^{4}$ The COSO is a joint initiative sponsored by five of the most prominent professional accounting organizations: American Accounting Association (AAA), American Institute of Certified Public Accountants (AICPA), Financial Executives International (FEI), Institute of Internal Auditors (IIA), and Institute of Management Accountants (IMA).
} 
far, the FASB has only been involved in E\&S issues when they directly overlap with financial reporting (e.g., environmental liabilities and asset retirement obligations). This study demonstrates an important interaction between E\&S performance and financial reporting. The extent to which the summary measures of earnings and book value are reflected in firm value demonstrates how E\&S risks induce a partial shift from recursion value to adaptation value.

The remainder of this paper is structured as follows. Section II presents theoretical and practical background to develop my hypotheses. Section III describes the research design and defines the key variables used in my analyses. The sample selection and descriptive statistics of the data are presented in section IV. Section V presents the results of my primary empirical analyses supporting my hypotheses and Section VI offers several additional tests used to strengthen the primary findings. Finally, I provide a summary and conclusion of the study in section VII.

\section{BACKGROUND AND HYPOTHESIS DEVELOPMENT}

\subsection{Institutional Theory}

Institutional theory, rooted in sociology, is focused on how organizations obtain legitimacy with their stakeholders (Meyer and Rowan 1977; DiMaggio and Powell 1983). ${ }^{5}$ Specifically, institutional theory states that the prevailing institutional norms define the criteria by which external stakeholders evaluate a firm's legitimacy. Organizations operating in accordance with these institutional norms obtain legitimacy with its stakeholders (Baum and Oliver 1991). A principal benefit of legitimacy is increased survival capabilities (Meyer and Rowan 1977;

\footnotetext{
${ }^{5}$ In this context, legitimacy is synonymous with reputational capital.
} 
DiMaggio and Powell 1983). Legitimacy is necessary for a firm to have the social license to continue operating according to its current approach.

Academic literature and business press indicate that CSR has been institutionalized over the past few decades (Campbell 2007). Investors and other stakeholders have come to expect socially responsible behavior. Bialkowlski and Starks (2018) show that media mentions of social responsibility and demand for socially responsible investment have increased dramatically since 1999. Accordingly, research has shown CSR is an effective method to enhance a firm's legitimacy among its customers, employees, and other stakeholders (e.g., Brown and Dacin 1997; Handelman and Arnold 1999; Sen and Bhattacharya 2001; Killian and O’Regan 2016).

\subsection{Environmental and Social Risk}

Institutional theory suggests that firms hoping to continue their current operating processes in the long term must address concerns of weak CSR. CSR is a broad concept that typically refers to "business practices based on ethical values, with respect for people, communities, and the environment" (Bhimani and Soonawalla 2005). Within the broader CSR construct, environmental performance aims to reduce any damaging effects of operations on the natural environment. Social performance aims to limit harm to customers, employees, stakeholders, and the community at large. Instances of companies failing to identify, prevent, and respond to environmental or social risks continue to rise (WBCSD 2017).

In February 2018, the COSO released guidance on addressing E\&S risks. The guidance is largely motivated by mounting pressure from investors and consumers for firms to demonstrate positive E\&S performance. It is widely believed that failure to respond to E\&S concerns can have 
adverse effects on a firm's profitability, success, and survival. ${ }^{6}$ Specifically, the COSO argues that a company's medium and long-term viability depend on the ability to identify and respond to E\&S risks (COSO 2018). Firms facing E\&S risks are forced to modify their operations if they hope to maintain their social license to operate.

Consider the prominent example of Facebook, which was recently pressured to address weaknesses in its social performance. In early 2018, Facebook was criticized for several alleged social offenses, most notably its perceived careless data security policies. ${ }^{7}$ As a result, CEO Mark Zuckerberg was called to testify before Congress on April 11, 2018. In preparation for this testimony, Sen. Richard Blumenthal (D., Conn.) claimed "There is a more fundamental issue related to Facebook's business model — they sell your information without your consent" (Hughes 2018). Facebook's business model was centered on generating advertising revenue, largely through targeted advertising made possible by collecting user data. Because of public and government pressure regarding this social concern, Facebook initiated several changes to its operations including expanded privacy settings and reduced access to user data. Zuckerberg himself stated that these moves will significantly impact profitability going forward as the changes reduce the viability of its targeted advertising strategy (Hughes 2018). This is just one practical example illustrating how firms facing E\&S risk may be forced to adapt their operations, causing current earnings to be a less accurate predictor of future earnings.

\footnotetext{
${ }^{6}$ Major accounting firms likewise contend that nonfinancial E\&S performance has become intertwined with financial performance (EY 2011; Deloitte 2017).

${ }^{7}$ Most notably, Cambridge Analytica, a British political consulting and data analytics firm, had inappropriate access to data of up to 87 million Facebook users (Wells and McKinnon 2018).
} 


\subsection{Recursion Value and Adaptation Value in Firm Valuation}

The price of a firm's stock reflects the present value of all expected future dividends to the shareholder. Current earnings and expected future earnings combine to form expectations about future dividends, which in turn form the basis of firm value (Nichols and Wahlen 2004). Expectations of future earnings can be modeled as a function of expected recursion and adaptation because at any point in time a firm has the option to either continue or adapt current operations. Recursion value is the value of capitalized future earnings assuming the firm continues to operate according to its current business strategy. Adaptation value is the value of the firm's option to liquidate or redeploy its assets.

Current earnings are a measure of current period wealth creation generated by current operating processes. Current earnings relate to the concept of recursion value because current earnings are likely the best proxy for future earnings if the firm's current earnings generating processes remain unchanged in future years (Burgstahler and Dichev 1997). However, E\&S risks are a threat to the continuity of future cash flows. When firms face E\&S risk, they may not have the option to continue their current operations. In such a situation, current earnings contribute limited useful information for prediction of future dividends, and investors must rely on alternate information in their valuation model. When current earnings are unlikely to persist, the value of a firm's resources independent of its current operations may better reflect the firm's ability to generate future earnings streams. Accordingly, a partial shift to adaptation value is expected when the current earnings generating process is expected to be modified. Book value is closely related to the concept of adaptation value because book value is a cost-based measure of a firm's resources without consideration for how they will be used. 
In summary, the value of the firm can be expressed as a function of both earnings ("recursion value") and book value ("adaptation value") with the relative valuation weights of each component depending on the likelihood that the current earnings generating process will persist. Investors seeking to assess the nature, timing, and extent of future earnings and dividends likely adjust their model in the presence of E\&S risk. Because firms facing E\&S risk are likely to be required to adapt or terminate their operations, I predict that recursion value (adaptation value) is relatively less (more) important in valuation when firms face E\&S risk. ${ }^{8}$ I formally state these hypotheses as follows:

H1: The association between firm value and current earnings ("recursion value") is lower when environmental and social risks are present.

$\mathrm{H} 2$ : The association between firm value and book value ("adaptation value") is higher when environmental and social risks are present.

\subsection{The Role of Asset Tangibility}

For the average firm, corporate resources have shifted dramatically from tangible assets to intangible assets. The rate of investment in intangible assets has surpassed the rate of investment in tangible assets (Monga 2016). Newly listed firms have particularly become more intangible intensive over time (Srivistava 2014). Asset tangibility is likely to impact the shift to adaptation value because tangible assets have greater alternate use and less dependence on firm reputation relative to recorded intangible assets.

Adaptation value is the value of the option to liquidate or redeploy a firm's assets. Assets which are redeployable have higher adaptation and liquidation values (Williamson 1988). Tangible assets are expected to have greater redeployability than recorded intangible assets. Most

\footnotetext{
${ }^{8}$ Note that this study focuses on investor perception of the likelihood of adaptation. Whether, and how, firms ultimately choose to adapt their operations are questions left for future research.
} 
intangible assets are specialized in nature, limiting the ability to be redeployed (Shleifer and Vishny 1992). Thus, in liquidation, recorded intangible assets are likely to have zero, or close to zero, value (Holthausen and Watts 2001). For example, patents, trademarks, and goodwill have limited or no use outside of their defined purpose. These recorded intangible assets usually generate value jointly with specific tangible assets and business technology. Based on the greater redeployability and liquidation value of tangible assets, adaptation value is expected to be positively associated with the tangibility of assets.

Further, tangible assets are less likely than recorded intangible assets to be impacted by damage to the firm's reputation. The value of knowledge-based and intangible assets is largely dependent on the reputation of the company among its stakeholders and the public (Daum 2003; Godfrey, Merrill, and Hansen 2009). For example, goodwill is often one of the largest assets reported on the balance sheet and is largely comprised of the reputation of acquired entities. ${ }^{9}$ Conversely, corporate reputation is not reflected in the recorded value of most tangible fixed assets. According to institutional theory, E\&S performance is a critical factor in cultivating a positive firm reputation. As such, firms facing $E \& S$ risk are expected to experience a decrease in value of reputational based intangible assets.

In summary, tangible assets are expected to be more adaptable and less dependent on reputation than intangible assets. For these reasons, I predict that the shift to adaptation value in the presence of E\&S risk is stronger for firms with a higher asset tangibility. This prediction is formally stated in Hypothesis 3 as follows:

\footnotetext{
${ }^{9} \mathrm{Li}$ and Sloan (2017) found the average goodwill balance during the sample period from 2004-2011 to be $14.6 \%$ of total assets.
} 
H3: The increase in the association between firm value and current book value ("adaptation value") in the presence of environmental and social risk is stronger for firms with high asset tangibility.

\section{VARIABLE MEASUREMENT AND RESEARCH DESIGN}

\subsection{Adaptation Value and Recursion Value}

The primary objective of my analyses is to examine the role of recursion value and adaptation value in the presence of E\&S risk. As neither recursion value nor adaptation value are directly observable, it is necessary to identify empirical proxies for these constructs. ${ }^{10}$

Following prior literature, I use current earnings as a proxy for recursion value (Burgstahler and Dichev 1997; Rabier 2018). Prior research generally shows that current earnings are a good predictor of future earnings (e.g., Ball and Watts 1972; Finger 1994). By definition, current earnings are the results of operating according to the firm's current business strategy. If the firm is expected to continue operating according to its current approach, current earnings are expected to be a good proxy for future earnings.

If current operations do not satisfy expectations in terms of either financial or social performance, the firm may liquidate assets or be forced to redeploy them in a more satisfactory way. Adaptation value is defined as the value of this option to liquidate or redeploy the firm's assets. This value is independent of current operations. Following prior literature, I use book value as a proxy for adaptation value (Burgstahler and Dichev 1997; Rabier 2018). Book value is closely related to the concept of adaptation value because book value is a cost-based measure of firm resources independent of their current use. More specifically, I use book value at the end of year $t-1$ as the proxy for adaptation value in year $t$. Mechanically, book value at the end of year $t$

\footnotetext{
${ }^{10}$ Note that while the chosen proxy variables likely measure the underlying constructs with error, they do not do so in a way that should bias results.
} 
includes earnings for year $t$. As such, using book value at the end of year $t-1$ allows for a clearer separation of the effects of earnings ("recursion value") and book value ("adaptation value") (Burgstahler and Dichev 1997). ${ }^{11}$

\subsection{Environmental and Social Risk}

The primary independent variable of interest in my analyses is a measure of the firm's E\&S risk. I identify the presence of E\&S risk using CSR ratings from the MSCI KLD Analytics database (KLD). KLD analysts annually rate firms across the social dimensions of product quality and safety, employee relations, environment, community, diversity, and human rights. ${ }^{12}$ In each of these dimensions, KLD analysts use a variety of sources to rate firms in a binary fashion on many positive indicators ("strengths") and negative indicators (“concerns"). Appendix A provides a discussion of the approach used by KLD and a summary of social performance dimensions considered.

While there are many available resources to operationalize the CSR construct, multiple factors point towards the KLD database being the most appropriate for my research question. First, as the most comprehensive publicly available data on CSR, KLD data has been used extensively in accounting research (e.g., Kim, Park, and Wier 2012; Hoi, Wu, and Zhang 2013) and has passed several reliability and validity tests (Swajkowski and Figlewicz 1999; Mattingly and Berman 2006). Second, many other CSR databases (e.g., ASSET4) present composite scores that are difficult to interpret regarding E\&S risk. By directly identifying and rating concern attributes,

\footnotetext{
${ }^{11}$ The research design choice between $\mathrm{BV}_{\mathrm{t}-1}$ and $\mathrm{BV}_{\mathrm{t}}$ has no effect on the conclusions of this study. In untabulated analyses using $\mathrm{BV}_{\mathrm{t}}$ as the proxy for adaptation value all results remain qualitatively unchanged from the results presented using $\mathrm{BV}_{\mathrm{t}-1}$.

${ }^{12} \mathrm{KLD}$ also rates firms on the exclusionary categories of alcohol, firearms, gambling, military contracting, nuclear power, and tobacco. Following prior literature, these exclusionary categories are not included in my analysis because they are primarily determined by industry characteristics outside of the firm's discretion.
} 
KLD allows for a clear identification of firms facing E\&S risk. Finally, this study views E\&S concerns as a risk to the continuity of financial performance. Many of the attributes rated by KLD are specifically defined in terms of a financial risk attributable to an $\mathrm{E} \& \mathrm{~S}$ concern. ${ }^{13}$

My primary measure of E\&S risk is based on the firm's net CSR performance. I calculate a net CSR performance score as the sum of strengths minus the sum of concerns in the following six social performance dimensions: product quality and safety, employee relations, environment, community, diversity, and human rights. Firms with greater concerns than strengths are most likely to face E\&S risk. As such, I define $E \& S R I S K$ as an indicator variable equal to one if the firm's net CSR performance score in year $t$ is negative, and zero otherwise. ${ }^{14}$

\subsection{Research Design}

Following Ohlson (1995) and Collins, Maydew, and Weiss (1997), a firm's share price can be modeled as a function of its earnings and book value as follows:

$$
\operatorname{PRICE}_{i, t}=\alpha_{0}+\alpha_{1} E A R N_{i, t}+\alpha_{2} B V_{i, t-1}+\varepsilon_{i, t}
$$

where $P R I C E_{i, t}$ is the price per share of firm $i$ three months after fiscal year-end $t, E A R N_{i, t}$ is earnings before extraordinary items per share of firm $i$ during year $t$, and $B V_{i, t-1}$ is the book value of equity per share of firm $i$ at the end of year $t-1$.

My first approach for comparing the value relevance of earnings and book value is to use an $\mathrm{R}^{2}$ decomposition technique that has been used widely in prior research (e.g., Easton 1985; Collins et al. 1997). The total explanatory power of earnings and book value on prices can be decomposed into three components: (1) the incremental explanatory power of earnings, (2) the

\footnotetext{
${ }^{13}$ For example, the environmental attribute of "Natural Resource Use - Water Stress" is specifically defined by KLD as an assessment of "how companies manage the risks of water shortages impacting their ability to operate, losing access to markets due to stakeholder opposition over water use, or being subject to higher water costs".

${ }^{14}$ Additionally, I reperform my primary analysis with several alternate measures of E\&S risk. These results are discussed in sections 6.3 through 6.5 with all findings qualitatively unchanged from those using the primary measure.
} 
incremental explanatory power of book value, and (3) the portion of explanatory power that is common to both earnings and book value. For this $\mathrm{R}^{2}$ decomposition approach, the following models are used to estimate the explanatory power of earnings and book value, respectively:

$$
\begin{gathered}
\text { PRICE }_{i, t}=\beta_{0}+\beta_{1} E_{A R N_{i, t}+\varepsilon_{i, t}} \\
\text { PRICE }_{i, t}=\gamma_{0}+\gamma_{1} B V_{i, t-1}+\varepsilon_{i, t}
\end{gathered}
$$

I denote the $\mathrm{R}^{2}$ from models (1), (2) and (3) as $R_{\text {Total }}^{2}, R_{E A R N}^{2}$, and $R_{B V}^{2}$, respectively. $R_{\text {Total }}^{2}$ represents the total explanatory power of earnings and book value combined. The incremental explanatory power of book value is defined as $R_{\text {Total }}^{2}-R_{E a r n}^{2}$ and the incremental explanatory power of earnings is calculated as $R_{\text {Total }}^{2}-R_{B V}^{2}$. The remainder $\left(R_{\text {Total }}^{2}-R_{\text {Earn }}^{2}-R_{B V}^{2}\right)$ represents the explanatory power common to both earnings and book value.

I use this $\mathrm{R}^{2}$ decomposition technique to provide initial evidence of how E\&S risk is reflected in the value relevance of earnings and book value. Specifically, I compare the incremental value relevance of earnings and book value between $E \& S$ risk firms and non-E\&S risk firms. H1 predicts that the incremental value relevance of earnings is lower for E\&S risk firms compared to non-E\&S risk firms. H2 predicts that the incremental value relevance of book value is higher for $E \& S$ risk firms compared to non-E\&S risk firms.

In addition to comparing the incremental $\mathrm{R}^{2}$ values as described above, another approach to investigate how E\&S risk is reflected in the value relevance of earnings and book value is through an examination of coefficients. I modify model (1) to include a variable for E\&S risk and its interaction with earnings and book value. This approach begins with the following base model:

$$
\begin{aligned}
\operatorname{PRICE}_{i, t}=\alpha_{0} & +\alpha_{1} E_{A R N_{i, t}}+\alpha_{2} B V_{i, t-1}+\alpha_{3} E \& S \text { RISK }_{i, t}+\alpha_{4} E \& S R I S K_{i, t} \\
& * E A R N_{i, t}+\alpha_{5} E \& S \operatorname{RISK}_{i, t} * B V_{i, t-1}+\text { Year FE }+ \text { Firm FE }+\varepsilon_{i, t}
\end{aligned}
$$


where $E \& S R I S K$ is equal to one if firm $i$ faces environmental or social risk in year $t$, and zero otherwise. Specifically, I calculate a CSR score as total strengths minus total concerns across the MSCI KLD Analytics dimensions of product quality and safety, employee relations, environment, community, diversity, and human rights. E\&S RISK is equal to one if the calculated CSR score is negative, and zero otherwise. All other variables are as defined previously. I include year and firm fixed effects to control for systematic differences in prices over time and across firms. Finally, standard errors are clustered by firm in all analyses.

The coefficient on $\operatorname{EARN}(B V)$ captures the valuation weight on current earnings (book value) when $\mathrm{E} \& \mathrm{~S}$ risk is minimal (i.e., when $E \& S$ RISK equals zero). The coefficient on the interaction of $E \& S$ RISK and $E A R N(B V)$ captures the incremental valuation weight on current earnings (book value) when the firm faces $\mathrm{E} \&$ S risk (i.e., when $E \& S R I S K$ equals one).

Firm characteristics differ on average between high social responsibility firms and low social responsibility firms. Model (4) is modified to include control variables and their interactions with earnings and book value based on factors identified by prior research. ${ }^{15}$ The resulting model (5) is as follows:

$$
\begin{gathered}
\text { PRICE }_{i, t}=\beta_{0}+\beta_{1} E_{\text {ERN }}+\beta_{2, t} \text { BV }_{i, t-1}+\beta_{3} \text { E\&S Risk }_{i, t}+\beta_{4} E \& S \text { Risk }_{i, t} * \\
\text { EARN }_{i, t}+\beta_{5} E \& S \text { Risk }_{i, t} * \text { BV }_{i, t-1}+\beta_{6} \text { Size }_{i, t}+\beta_{7} \text { Size }_{i, t} * E \text { ARN }_{i, t}+ \\
\beta_{8} \text { Size }_{i, t} * B V_{i, t-1}+\beta_{9} \text { Leverage }_{i, t}+\beta_{10} \text { Leverage }_{i, t} * \text { EARN }_{i, t}+ \\
\beta_{11} \text { Leverage }_{i, t} * B V_{i, t-1}+\text { Year FE }+ \text { Firm FE }+\varepsilon_{i, t}
\end{gathered}
$$

Hayn (1995) shows that smaller firms are more likely to report losses than larger firms and have lower earnings persistence. Further, investors should place greater weight on book value

\footnotetext{
${ }^{15}$ Burgstahler and Dichev (1997) perform a capitalization factor sensitivity analysis in which they obtain assurance that their results are not attributable to factors related to leverage and size. I include these two variables, as well as their interaction with earnings and book value, as control variables in model 5.
} 
when valuing smaller companies because smaller firms are likely to include startup companies that are driven by future earnings growth potential rather than current earnings realizations (Collins et al. 1997). These smaller firms are likely to have less resources to invest in CSR resulting in a lower average CSR performance. For these reasons, I control for firm size by including the variable SIZE, which is defined as the natural log of total assets at the end of year $t$.

Firms with high debt are also less likely to engage in high levels of CSR (McGuire, Sundgren, and Schneeweis 1988; Benlemlih 2017). Dhaliwal, Lee, and Fargher (1991) document an inverse relationship between financial leverage and earnings informativeness. Combined, this research suggests that highly levered firms will have less informative earnings and lower average CSR performance. Therefore, I include the control variable LEVERAGE, calculated as total longterm debt divided by total assets at the end of year $t$.

\section{SAMPLE SELECTION AND DESCRIPTIVE STATISTICS}

\subsection{Sample Selection Procedures}

The most restrictive data source used in this study is the MSCI KLD Analytics (KLD) database used to identify the presence of E\&S risk. Over time, the KLD database has evolved to cover firms in the MSCI KLD 400 Social Index, MSCI USA Index, MSCI USA IMI Index, and the 1,000 largest US companies by market capitalization. The ratings provided by KLD to determine the existence of E\&S risk are available and able to be merged with Compustat for 32,045 firm-year observations. I first eliminate firms with negative earnings before extraordinary items because prior research (e.g., Hayn 1995; Collins et al. 1997; Joos and Plesko 2005; Jan and Ou 2012) show that loss firms are already priced towards adaptation value. Next, I eliminate observations with negative book value of equity because I use book value as a proxy for adaptation 
value, and negative book values lack economic meaning in this context (Collins et al. 1999). ${ }^{16}$ Additionally, firms are required to have all necessary Compustat and CRSP variables to calculate share price, earnings, book value, and all control variables. These sample restrictions result in a reduction of 7,270 observations. The final sample includes 24,775 firm-year observations from 1995 to 2015 , consisting of 9,912 observations with identified E\&S risk and 14,863 observations without identified E\&S risk. Firms in regulated industries (utilities and financial services) are commonly excluded from valuation focused research. Absent a reason to believe the predictions of this study would not apply to firms in regulated industries, these firms are included in the sample. ${ }^{17}$ Table 1 details the sample selection process and composition.

\subsection{Descriptive Statistics}

Table 2 reports descriptive statistics of the variables used in the empirical analyses. Refer to Appendix B for complete variable definitions. All continuous variables have been winsorized at the $1^{\text {st }}$ and $99^{\text {th }}$ percentiles to mitigate the effect of extreme outliers. The mean value of $E \& S$ RISK (0.4001) indicates that $40.01 \%$ of the firm-year observations in the sample face E\&S risks. The prevalence of these risks further motivates studying their valuation implications.

Table 3 reports the correlation matrix for all variables used in the analyses. Pearson correlations are presented in the upper-right cells and Spearman correlations are presented in the bottom-left cells. As expected, the correlation between E\&S RISK and EARN is significantly negative. This is consistent with previous studies (e.g., Lys, Naughton, and Wang 2015), which have found that firms with strong financial performance are more likely to have strong social

\footnotetext{
${ }^{16}$ In untabulated analyses, all results are qualitatively unchanged when including negative book value observations.

${ }^{17}$ All results are qualitatively unchanged when excluding firms in the utilities and financial services industries.
} 
performance. Accordingly, empirical tests have been designed to rule out poor financial performance of E\&S risk firms as an alternate explanation for my findings. ${ }^{18}$

\section{EMPIRICAL RESULTS}

\subsection{E\&S Risk and the Valuation Role of Earnings and Book Value (H1 and H2)}

Table 4 details the results of annual and pooled regressions of models (1) - (3). Panel A presents the results for observations where $E \& S R I S K$ equals zero, panel B presents the results for observations where $E \& S R I S K$ equals one. The adjusted $\mathrm{R}^{2}$ for the pooled regression indicates that earnings and book values together explain about $52.5 \%(53.7 \%)$ of the variation in share prices for firms with $E \& S R I S K$ equal to zero ( $E \& S R I S K$ equal to one). The final two columns in this table calculate the incremental explanatory power on share prices of earnings and book value, respectively. The incremental explanatory power of earnings represents the ability of earnings to explain share prices beyond the information in book value and is calculated as the adjusted $\mathrm{R}^{2}$ of model (1) minus the adjusted $\mathrm{R}^{2}$ of model (3). The incremental explanatory power of book value represents the ability of book value to explain share prices beyond the information in earnings and is calculated as the adjusted $\mathrm{R}^{2}$ of model (1) minus the adjusted $\mathrm{R}^{2}$ of model (2).

Hypotheses 1 and 2 predict that the value relevance of earnings (book value) is lower (higher) when firms face E\&S risks. My first approach to investigate this prediction is through comparing the incremental explanatory power on share prices of earnings and book value between firms with E\&S risk and firms without E\&S risk. This comparison is presented in Panel C of Table 4 and graphically in Figure 1. Panel A of Figure 1 compares the incremental explanatory power of earnings between firms with E\&S risk and firms without E\&S risk. In nearly all years, earnings

\footnotetext{
${ }^{18}$ See discussion in section 6.1 with results presented in Table 7.
} 
have greater incremental explanatory power for firms with no E\&S risk. Panel B of Figure 1 compares the incremental explanatory power of book value between firms with E\&S risk and firms without E\&S risk. In nearly all years, book value has greater incremental explanatory power for firms with E\&S risk. Combined, these results present initial evidence supporting H1 and H2. Firm value partially shifts from recursion value to adaptation value in the presence of E\&S risk.

In addition to comparing the incremental $\mathrm{R}^{2} \mathrm{~s}$, I also test the impact of E\&S risk on the value relevance of earnings and book values through an examination of regression coefficients. Table 5 presents results of estimating models (4) and (5). Column 1 presents the results of estimating the baseline model without control variables (model 4). The coefficients on the interaction between $E \& S R I S K$ and $E A R N(-1.714)$ is significantly negative (p < 0.01$)$, and the coefficient on the interaction between $E \& S R I S K$ and $B V(0.184)$ is significantly positive $(\mathrm{p}<0.01)$. Column 2 presents the results of estimating the expanded model including control variables (model 5). The coefficients on the interaction between $E \& S R I S K$ and $E A R N(-1.687)$ is significantly negative $(\mathrm{p}<0.01)$ and the coefficient on the interaction between $E \& S R I S K$ and $B V$ $(0.146)$ is significantly positive $(\mathrm{p}<0.01)$. In both model specifications, the value relevance of earnings (book value) is lower (higher) in the presence of E\&S risks. These results are consistent with my findings from the preceding $\mathrm{R}^{2}$ decomposition analysis and further support $\mathrm{H} 1$ and $\mathrm{H} 2$.

\subsection{The Role of Asset Tangibility (H3)}

Results so far indicate that E\&S risk impacts the value relevance of earnings ("recursion value") and book value ("adaptation value"). Hypothesis 3 predicts that the relation between E\&S risk and adaptation value is especially salient for firms with high asset tangibility. To examine this research question, I repeat the preceding analysis on subsamples partitioned on asset tangibility. I classify a firm as high (low) tangibility if its calculated asset tangibility is above 
(below) the industry-year median asset tangibility. My primary measure of asset tangibility (TANGIBILITY) is defined as current assets plus net property, plant and equipment divided by total assets. This measure is designed to best capture a firm's ability to redeploy its assets for an alternate use. As a secondary measure, I define TANGIBILITY PPE as net property, plant, and equipment divided by total assets for consistency with measures of asset tangibility used in prior research (e.g., Rajan and Zingales 1995; Baker and Wurgler 2002; Bharath, Sunder, and Sunder 2008; Lara, Osma, and Penalva 2016). ${ }^{19}$

Table 6 presents the results of estimating models (4) and (5) separately for the subsamples of firms with high asset tangibility and low asset tangibility. Panel A presents the results of the primary analysis using TANGIBILITY as the partitioning variable. Columns 1 and 2 employ the baseline model without control variables (model 4). The coefficient on $E \& S R I S K * B V(0.245)$ is significantly positive $(\mathrm{p}<0.01)$ in the high tangibility subsample, but the coefficient on $E \& S R I S K * B V(0.110)$ is not statistically different from zero in the low tangibility subsample. Columns 3 and 4 employ the expanded model including control variables (model 5). The coefficient on $E \& S R I S K * B V(0.228)$ is significantly positive (p < 0.01$)$ in the high tangibility subsample, but the coefficient on $E \& S R I S K * B V(0.105)$ is not statistically different from zero for the low tangibility subsample. Interestingly, the coefficients on $E \& S R I S K * E A R N$ are significantly negative in both low and high tangibility subsamples. These results are consistent with my expectations. In the presence of E\&S risk, future earnings are at risk, and I find the associated decline in the value relevance of earnings for both high tangibility and low tangibility firms. However, as predicted by Hypothesis 3, I find the concurrent increase in value relevance

\footnotetext{
${ }^{19}$ Another alternate measure of asset tangibility used in recent research is the sum of net PPE plus inventory divided by total assets (Kraft 2015). In an untabulated analysis using this alternate measure of asset tangibility all results are qualitatively unchanged from the tabulated analyses.
} 
of book value is only statistically significant for firms with high asset tangibility, consistent with greater adaptability of tangible assets.

Panel $\mathrm{B}$ of Table 6 repeats the preceding analysis using TANGIBILITY PPE as the partitioning variable. Columns 1 and 2 employ the baseline model without control variables (model 4). The coefficient on $E \& S R I S K * B V(0.234)$ is significantly positive $(\mathrm{p}<0.01)$ in the high tangibility subsample, while the coefficient on $E \& S R I S K * B V(0.137)$ is much smaller and only marginally significant $(\mathrm{p}<0.10)$ in the low tangibility subsample. Columns 3 and 4 employ the expanded model including control variables (model 5). The coefficient on $E \& S R I S K * B V$ $(0.190)$ is significantly positive $(\mathrm{p}<0.05)$ in the high tangibility subsample, but the coefficient on $E \& S R I S K * B V(0.107)$ is not statistically different from zero for the low tangibility subsample. Again, the coefficients on $E \& S R I S K * E A R N$ are significantly negative in both low and high tangibility subsamples. All results from Panel B of Table 6 are comparable with those from Panel A and continue to support Hypothesis 3.

\section{ADDITIONAL ANALYSES}

\subsection{Cross-Sectional Analysis: Financial Performance}

Firms with poor financial performance are likely to have weaker environmental and social performance (Waddock and Graves 1997; Lys et al. 2015). This is evidenced by the significant negative correlation between $E \& S R I S K$ and $E A R N$ in Table 3. Prior research has shown that financial performance impacts the value relevance of earnings and book values. When firms face financial distress, value relevance shifts from earnings to book value consistent with an increased importance of adaptation value in firm valuation (Burgstahler and Dichev 1997; Collins et al. 1997; Barth et al. 1998; Jan and Ou 2012). These relationships create an interesting opportunity to investigate the mechanism driving my results. If my results are driven by the weak financial 
performance associated with poor E\&S performance, results should be strongest in firms with poor financial performance. However, if results are driven by poor E\&S performance causing a perceived need for adaptation as my theory predicts, results should be strongest for the sample of firms that are not already priced close to adaptation value for reasons of financial distress (i.e., firms with strong financial performance).

Table 7 presents results of estimating models (4) and (5) after partitioning the sample at the industry-year median return-on-assets (ROA). Results of this analysis are consistent with the theory underlying my predictions. The coefficient on E\&S RISK *EARN (-2.623) is negative and statistically significant $(\mathrm{p}<0.01)$ in the high ROA subsample but not statistically significant in the low ROA subsample. The difference in these coefficients is statistically significant at the $p<0.05$ threshold. The coefficient on $E \& S R I S K * B V(0.312)$ is positive and statistically significant (p < 0.01) in the high ROA subsample but not statistically significant in the low ROA subsample. The difference in these coefficients is statistically significant at the $p<0.05$ threshold. Overall, these results are evidence that the partial shift from recursion value to adaptation value is not driven by the negative correlation between E\&S risk and financial performance. Rather, E\&S risk appears to increase the perceived need for adaptation of otherwise well performing firms.

\subsection{Alternate Measure of Adaptation Value: Exit Value}

A major component of adaptation value is the option to completely liquidate operations. Accordingly, the value that can be generated in a liquidation would serve as a reasonable alternate proxy for the adaptation value construct. Berger, Ofek, and Swary (1996) estimate how many cents per dollar of book value various categories of assets generate when a business segment is discontinued. Their parameter estimates result in the following model to estimate a firm's exit value: 


$$
\begin{gathered}
\text { EXITVAL }_{t}=1.0 \text { Cash }_{t}+1.0 \text { Marketable Securities }_{t}+0.72 \text { Receivables }_{t}+ \\
0.55 \text { Inventory }_{t}+0.54 \text { Fixed Assets }_{t}-1.0 \text { Payables }_{t}-1.0 \text { Total Debt }_{t}
\end{gathered}
$$

Following prior research (Collins et al. 1999), I use the parameter estimates from this model to estimate a firm's exit value (EXITVAL). I impose the restriction that EXITVAL $\geq 0$ because a negative exit value has no economic meaning (Berger et al. 1996; Collins et al. 1999).

Table 8 presents results of estimating models (4) and (5) using EXITVAL as the proxy for the adaptation value construct. All results are comparable with the primary specification. Consistent with expectations, the coefficient on E\&S RISK *EARN (-1.618) is negative and statistically significant ( $\mathrm{p}<0.01)$, and the coefficient on the E\&S RISK *EXITVAL $(0.128)$ is positive and statistically significant $(\mathrm{p}<0.05)$. These findings indicate that the results of this study are not sensitive to the research design choice of my primary measure of adaptation value.

\subsection{Alternate Measures of Environmental and Social Risks}

My primary measure of E\&S risk is calculated by netting total concerns with total strengths. This is the most commonly used approach in existing research and is the appropriate measurement of E\&S risk for this study because firms may invest in strengths to offset concerns that may be inherent to their industry or strategy (Farnsel and Hennes 2019). However, this measure also has certain limitations. To address these limitations, I reperform my primary analyses with several alternate measures of $\mathrm{E} \& \mathrm{~S}$ risk.

First, it is conceivable to argue that not all environmental or social concerns are capable of being offset by strength attributes. To address this concern, I create an alternate measure of E\&S risk that considers only concern attributes. This alternate measure, E\&S RISK CONCERNS, is equal to one if the firm's total concerns in year $t$ across the six dimensions of E\&S performance is greater than the median level of total concerns in year $t$. Second, prior literature suggests that 
environmental and social performance varies between industries (e.g., Dhaliwal, Li, Tsang, and Yang 2014). In consideration of the role industry plays in the presence and perception of E\&S risk, I create an industry adjusted E\&S risk measure (IND ADJ E\&S RISK) that is equal to one if the firm's CSR score is below the industry-year median, and zero otherwise. Third, MSCI KLD Analytics does not take a singular approach to rating all firms. Instead, the specific attributes rated vary by industry and over time. To address this concern, I create an E\&S risk measure that normalizes a firm's E\&S performance score by the number of available attributes. Specifically, NORMALIZED E\&S RISK is equal to one if E\&S strengths divided by the number of rated strength attributes minus E\&S concerns divided by the number of rated concern attributes is negative, and zero otherwise.

Table 9 presents results of estimating models (4) and (5) when using these three alternate measures of E\&S risk. Columns 1 and 2 present the results including E\&S RISK CONCERNS as the measure of environmental and social risk. The coefficient on E\&S RISK CONCERNS * EARN $(-1.024)$ is negative and statistically significant $(\mathrm{p}<0.01)$, and the coefficient on the E\&S RISK CONCERNS * BV $(0.178)$ is positive and statistically significant $(\mathrm{p}<0.01)$. Columns 3 and 4 present the results including IND ADJ E\&S RISK as the measure of environmental and social risk. The coefficient on IND ADJ E\&S RISK *EARN (-1.339) is negative and statistically significant ( $\mathrm{p}<0.01$ ), and the coefficient on the IND ADJ E\&S RISK*BV(0.142) is positive and statistically significant $(\mathrm{p}<0.01)$. Columns 5 and 6 present the results including NORMALIZED $E \& S$ RISK as the measure of environmental and social risk. The coefficient on NORMALIZED E\&S RISK *EARN (-1.899) is negative and statistically significant $(\mathrm{p}<0.01)$, and the coefficient on the NORMALIZED E\&S RISK *BV (0.138) is positive and statistically 
significant $(\mathrm{p}<0.01)$. Overall, all conclusions from my primary analysis remain unchanged when using these alternate measures of environmental and social risk.

\subsection{Continuous Measures of Environmental and Social Risks}

My primary measure of E\&S risk is an indicator variable to capture the presence of $E \& S$

risk. Alternatively, E\&S risk can be measured with continuous variables to allow the extent of E\&S risk to vary. I next reperform my primary analysis with two continuous measures of E\&S risk. CONT SQRT E\&S RISK is equal to the square root of the absolute value of CSR score when CSR score is negative, and zero otherwise. Modeling a continuous measure of E\&S risk in this fashion allows for consideration of varying levels of $E \& S$ risk with the caveat that once E\&S risk is present, each incremental component of E\&S risk is likely to have a smaller incremental contribution to potential adaptation value. I also use a continuous linear measure of E\&S Risk (CONTINUOUS E\&S RISK) in which each incremental component of E\&S risk is treated as having an identical contribution to potential adaptation value. CONTINUOUS E\&S RISK is equal to the absolute value of CSR score when CSR score is negative, and 0 otherwise.

Table 10 presents results of estimating models (4) and (5) when using the continuous measures of E\&S risk. Columns 1 and 2 present the results including CONTINUOUS E\&S RISK as the measure of environmental and social risk. Consistent with expectations, the coefficient on CONTINUOUS E\&S RISK * EARN (-0.529) is negative and statistically significant ( $\mathrm{p}<0.01)$, and the coefficient on the CONTINUOUS E\&S RISK *BV (0.042) is positive and statistically significant ( $\mathrm{p}<0.10)$. Columns 3 and 4 present the results including CONT SQRT E\&S RISK as the measure of environmental and social risk. Consistent with expectations, the coefficient on CONT SQRT E\&S RISK * EARN (-1.130) is negative and statistically significant ( $\mathrm{p}<0.01)$, and the coefficient on the CONT SQRT E\&S RISK * BV (0.091) is positive and statistically significant 
$(\mathrm{p}<0.05)$. Overall, results using continuous measures of environmental and social risk continue to support my primary findings.

\subsection{Disaggregated Environmental and Social Risks}

I disaggregate my primary measure of E\&S risk to examine its major components separately. ENV RISK represents the presence of environmental risk and equals one if total strengths minus total concerns within the MSCI KLD Analytics environment dimension is negative, and zero otherwise. SOC RISK represents the presence of social risk and equals one if total strengths minus total concerns within the MSCI KLD Analytics dimensions of product quality and safety, employee relations, community, diversity, and human rights is negative, and zero otherwise.

Table 11 presents the results of estimating models (4) and (5) with the separate measures of environmental risk and social risk. The coefficients on ENV RISK *EARN (ENV RISK *BV) are significantly negative (positive) in all specifications. Similarly, the coefficients on SOC RISK *EARN (SOC RISK *BV) are significantly negative (positive) in all specifications. These results examining the separate impact of environmental risks and social risks are comparable with those using the combined measure of E\&S risk in Table 5 and indicate that my findings are not isolated to one single dimension of E\&S risk.

\subsection{Sensitivity to Exclusion of Neutral Firms}

Firms are included in the MSCI KLD Analytics database if they meet size thresholds or are included in certain MSCI indices. Being active in environmental and social performance dimensions is not a requirement to be included in the database. In the primary sample used for this study, 3,285 firms do not satisfy the criteria of any strength or concern attributes. I classify these firms as "neutral firms". In my primary analyses, neutral firms are appropriately classified 
as not having E\&S risk. However, neutral firms are inherently different than firms that participate in environmental and social performance and thus may not be an appropriate comparison group to include in the analysis. As a test of whether the results of this study are sensitive to the inclusion of neutral firms, I repeat the primary analysis with a sample that excludes neutral firms.

Table 12 presents results of estimating models (4) and (5) with a sample that excludes all neutral firm observations. All results are comparable with the results of my primary specification. Consistent with expectations, the coefficient on E\&S RISK *EARN (-1.589) is negative and statistically significant ( $\mathrm{p}<0.01)$, and the coefficient on the $E \& S R I S K * B V(0.117)$ is positive and statistically significant $(\mathrm{p}<0.05)$. These findings indicate that the results of this study are not sensitive to the inclusion of neutral firms in the sample.

\subsection{Sensitivity to Sample Period}

The sample for this study is obtained from the MSCI KLD Analytics database. Beginning in 2003, MSCI KLD Analytics added the MSCI USA IMI Index to the set of firms rated for environmental and social performance. Not only did this change significantly increase the number of firms included in the database, it allowed for the inclusion of a broader type of firm. ${ }^{20}$ While the early database focused on the MSCI KLD 400 Social Index and the largest US companies, the MSCI USA IMI Index includes over 2,400 large, mid, and small cap firms. As a test of whether the results of this study are sensitive to the changing sample composition, I repeat my primary analysis separately for the periods before and after the sample composition change in 2003.

Table 13 presents the results of estimating models (4) and (5) separately for the periods before and after the 2003 sample change. Results for both the pre and post periods are comparable

\footnotetext{
${ }^{20}$ As can be seen in Table 4 (by summing E\&S risk and non-risk firms), the sample of firms in my study increased from 698 in 2002 to 1,780 in 2003, a year-over-year increase of $155 \%$.
} 
with the primary results presented in Table 5. The coefficient on E\&SRISK*EARN is significantly negative for both periods. Similarly, the coefficient on $E \& S R I S K * B V$ is significantly positive for both periods. These results indicate that the results of this study do not appear to be sensitive to the changing sample composition of the MSCI KLD Analytics database.

\subsection{Alternate Classification of High and Low Asset Tangibility}

Hypothesis 3 predicts that firms with more tangible assets experience a greater shift to adaptation value in the presence of environmental and social risk. In my primary analysis, I use a within industry approach to classify observations as high or low tangibility because there are different expected levels of tangible assets inherent to each industry's common operations. Accordingly, a firm is expected to have high adaptability of assets if the assets are more tangible than the expected level for the firm's industry. A limitation of this primary approach for tangibility classification is that it forces half the firms in an industry to be classified as low tangibility. An alternate perspective is that because some industries are characterized by more adaptable assets than other industries, firms should be classified as high tangibility or low tangibility without regard for how they compare with industry peers. In consideration of this perspective, I perform an additional analysis in which I classify observations as high (low) tangibility if the firm-year TANGIBILITY value is above (below) the annual median TANGIBILITY value.

Table 14 presents the results of estimating models (4) and (5) separately for the subsamples of firms with high asset tangibility and low asset tangibility when partitioned on the annual median value of TANGIBILITY. Columns 1 and 2 employ the baseline model without control variables (model 4). The coefficient on $E \& S R I S K * B V(0.207)$ is significantly positive $(\mathrm{p}<0.05)$ in the high tangibility subsample, but the coefficient on $E \& S R I S K * B V(0.142)$ is not statistically different from zero in the low tangibility subsample. Columns 3 and 4 employ the expanded model 
including control variables (model 5). The coefficient on $E \& S R I S K * B V(0.197)$ is significantly positive ( $\mathrm{p}<0.05)$ in the high tangibility subsample, but the coefficient on $E \& S R I S K * B V(0.139)$ is not statistically different from zero for the low tangibility subsample. As expected, the coefficients on $E \& S R I S K * E A R N$ are significantly negative in both low and high tangibility subsamples. These results are consistent with results of the primary analysis presented in Table 6 and further support Hypothesis 3. When classifying firms as high tangibility and low tangibility without regard for industry, I continue to find a significant increase in the value relevance of book value only for firms with high asset tangibility.

\section{CONCLUSION}

This study investigates the impact of environmental and social (E\&S) risks on firm value. Prior research has shown that firm value is a function of both recursion value and adaptation value, with the relative importance of each being a function of financial performance (Burgstahler and Dichev 1997; Barth et al. 1998; Collins et al. 1999). Contributing to this line of research, this study examines the influence of E\&S risk on the relative importance of recursion value (i.e., earnings) and adaptation value (i.e., book value). I find that when $\mathrm{E} \& \mathrm{~S}$ risks are present, there is a partial shift from recursion value to adaptation value (i.e., the association between firm value and earnings is lower, while the association between firm value and book value is higher). These results are consistent with institutional theory, which suggests that firms with poor E\&S performance face pressure from stakeholders and society at large to adapt or terminate their current operations. Further, I find that the partial shift to adaptation value is stronger for firms with high asset tangibility, consistent with intangible assets being less adaptable.

My analyses employ a large sample of firms rated for E\&S performance by MSCI KLD Analytics. Both an $\mathrm{R}^{2}$ decomposition analysis and an examination of regression coefficients 
indicate that earnings (book value) are relatively less (more) important in valuation in the presence of E\&S risk. My results are strengthened by several additional analyses. First, the influence of E\&S risk on recursion value and adaptation value is most pronounced for firms with strong financial performance, consistent with $E \& S$ risk increasing the perceived likelihood of adaptation in otherwise well performing firms. Second, results are robust to alternate measures of the underlying constructs of adaptation value and E\&S risk. Finally, I find that results not sensitive to sample selection considerations such as changing sample composition over time and inclusion of neutral CSR firms.

As corporate $\mathrm{E} \& \mathrm{~S}$ failures become more prominent, $\mathrm{E} \& \mathrm{~S}$ issues have received increased attention from stakeholders, practitioners, and society at large. Accordingly, calls have been made to understand the valuation implication of CSR (Hales et al. 2016; Joshi and Li 2016). Whereas most prior research attempts to link aspects of CSR directly to firm value, this study introduces adaptation as another channel through which CSR characteristics affect firm value. By demonstrating that the market prices firms with E\&S risk closer to adaptation value, this study supports the recent practitioner focus on corporate social responsibility as a risk to business continuity. 


\section{REFERENCES}

Baker, M. and J. Wurgler. 2002. Market timing and capital structure. The Journal of Finance. 57 (1): 1-32.

Ball, R. and R. Watts. 1972. Some time-series properties of accounting income. Journal of Finance. June: 663-682.

Barth, M. E., W. H. Beaver, and W. R. Landsman. 1998. Relative valuation roles of equity book value and net income as a function of financial health. Journal of Accounting and Economics. 25: 1-34.

Baum, J. A., and C. Oliver. 1991. Institutional linkages and organizational mortality. Administrative Science Quarterly: 187-218.

Bharath, S., J. Sunder, and S. Sunder. 2008. Accounting quality and debt contracting. The Accounting Review. 83 (1): 1-28.

Benlemlih, M. 2017. Corporate social responsibility and firm debt maturity. Journal of Business Ethics. 144 (3): 491-517.

Berger, P., E. Ofek, and I. Swary. 1996. Investor valuation of the abandonment option. Journal of Financial Economics. 42 (2): 259-287.

Bhimani, A. and K. Soonawalla. 2005. From conformance to performance: The corporate responsibilities continuum. Journal of Accounting and Public Policy. 24: 165-174.

Bialkowski, J., and L. T. Starks. 2018. SRI funds: Investor demand, exogenous shocks and ESG profiles. Working paper, University of Canterbury and University of Texas at Austin.

Brown, T. J., and P. A. Dacin. 1997. The company and the product: Corporate associations and consumer product responses. The Journal of Marketing. 61 (1): 68-84.

Burgstahler, D. C., and I. D. Dichev. 1997. Earnings, adaptation, and equity value. The Accounting Review. 72 (2): 187-215.

Campbell, J. L. 2007. Why would corporations behave in socially responsible ways? An institutional theory of corporate social responsibility. Academy of Management Review. 32 (3): 946-967.

Clarkson, P., Y. Li, and G. Richardson. 2004. The market valuation of environmental capital expenditures by pulp and paper companies. The Accounting Review. 79 (2): 329-353.

Collins, D. W., E. L. Maydew, and I. S. Weiss. 1997. Changes in the value-relevance of earnings and book values over the past forty years. Journal of Accounting and Economics. 24: 3967.

Collins, D. W., M. Pincus, and H. Xie. 1999. Equity valuation and negative earnings: The role of book value of equity. The Accounting Review. 74 (1): 29-61. 
Committee of Sponsoring Organizations of the Treadway Commission (COSO). 2018. Applying enterprise risk management to environmental, social, and governance-related risks. February 7. Available at https://www.coso.org/Documents/COSO-WBCSD-ReleaseNew-Draft-Guidance-Online-viewing.pdf

Daum, J. 2003. Intangible assets and value creation. John Wiley \& Sons.

Deloitte. 2017. Seek and you may find: How CFOs can manage sustainability risks and find longterm value. Available at https://www2.deloitte.com/content/dam/Deloitte/global/ Documents/Risk/gx-gra-sustainability-reporting.pdf

Dhaliwal, D. S., K. J. Lee, and N. L. Fargher. 1991. The association between unexpected earnings and abnormal security returns in the presence of financial leverage. Contemporary Accounting Research. 8 (1): 20-41.

Dhaliwal, D., O. Li, A. Tsang, and Y. Yang. 2014. Corporate social responsibility disclosure and the cost of equity capital: The roles of stakeholder orientation and financial transparency. Journal of Accounting and Public Policy. 33: 328-355.

DiMaggio, P., and W. W. Powell. 1983. The iron cage revisited: Collective rationality and institutional isomorphism in organizational fields. American Sociological Review. 48 (2): $147-160$.

Easton, P. D. 1985. Accounting earnings and security valuation: Empirical evidence of the fundamental links. Journal of Accounting Research. 23: 54-77.

EY. 2011. Climate change and sustainability: How sustainability has expanded the CFO's role. Available at https://www.ey.com/Publication/vwLUAssets/How_sustainability_has_ expanded_theCFOs_role/\$FILE/How_sustainability_has_expanded_CFO_role.pdf

Farnsel, C. and K. Hennes. 2019. Corporate social responsibility in the oil and gas industry. Oil, Gas, \& Energy Quarterly. 67 (3): 417-433.

Finger, C. 1994. The ability of earnings to predict future earnings and cash flow. Journal of Accounting Research. 32 (2): 210-223.

Godfrey, P. C., C. B., Merrill, and J. M. Hansen. 2009. The relationship between corporate social responsibility and shareholder value: An empirical test of the risk management hypothesis. Strategic Management Journal. 30: 425-445.

Hales, J., E. M. Matsumura, D. Moser, and R. Payne. 2016. Becoming sustainable: A rational decision based on sound information and effective processes? Journal of Management Accounting Research. 28 (2): 13-28.

Handelman, J. M. and S. J. Arnold. 1999. The role of marketing actions with a social dimension: Appeals to the institutional environment. The Journal of Marketing. 33-48.

Hayn, C. 1995. The information content of losses. Journal of Accounting and Economics. 20 (2): 125-153. 
Hoi, C. K., Q. Wu, and H. Zhang. 2013. Is corporate social responsibility (CSR) associated with tax avoidance? Evidence from irresponsible CSR activities. The Accounting Review. 88 (6): 2025-2059.

Holthausen, R. and R. Watts. 2001. The relevance of the value-relevance literature for financial accounting standard setting. Journal of Accounting and Economics. 31 (September): 3-75.

Hughes, S. 2018. Mark Zuckerberg: Facebook made mistakes on 'fake news', privacy. The Wall Street Journal. April 9.

Jan, C. L. and J. A. Ou. 2012. Negative-book-value firms and their valuation. Accounting Horizons. 26 (1): 91-110.

Joos, P. and G. A. Plesko. 2005. Valuing loss firms. The Accounting Review. 80 (3): 847-870.

Joshi, S. and Y. Li. 2016. What is corporate social sustainability and how do firms practice it? A management accounting research perspective. Journal of Management Accounting Research. 28 (2): 1-11.

Killian, S., and P. O'Regan. 2016. Social accounting and the co-creation of corporate legitimacy. Accounting, Organizations, and Society, 50: 1-12.

Kim, Y., M. S. Park, and B. Wier. 2012. Is earnings quality associated with corporate social responsibility? The Accounting Review. 87 (3): 761-796

Kraft, P. 2015. Do rating agencies cater? Evidence from ratings-based contracts? Journal of Accounting and Economics. 59: 264-283.

Li, K. and R. Sloan. 2017. Has goodwill accounting gone bad? Review of Accounting Studies. 22 (2): 964-1003.

Lys, T., J. Naughton, and C. Wang. 2015. Signaling through corporate accountability reporting. Journal of Accounting and Economics. 60 (1): 56-72.

Lara, J. M. G., B. G. Osma, and F. Penalva. 2016. Accounting conservatism and firm investment efficiency. Journal of Accounting and Economics. 61 (1): 221-238.

Malik. 2015. Value-enhancing capabilities of CSR: A brief review of contemporary literature. Journal of Business Ethics. 127 (2): 419-438.

Matsumura, E., R. Prakash, and S. Vera-Munoz. 2014. Firm-value effects of carbon emissions and carbon disclosures. The Accounting Review. 89 (2): 695-724.

Mattingly, J. E. and Berman, S.L. 2006. Measurement of corporate social action: Discovering taxonomy in Kinder Lydenberg Domini ratings data. Business and Society, 45, 20-46.

McGuire, J. B., A. Sundgren, and T. Schneeweis. 1988. Corporate social responsibility and firm financial performance. Academy of Management Journal. 31 (4): 854-872. 
Meyer, J. W. and B. Rowan. 1977. Institutionalized organizations: Formal structure as myth and ceremony. American Journal of Sociology. 83 (2): 340-363.

Monga, V. 2016. Accounting's 21 st century challenge: How to value intangible assets. The Wall Street Journal. March 21.

Nichols, D. C. and J. M. Wahlen. 2004. How do earnings numbers related to stock returns? A review of classic accounting research with updated evidence. Accounting Horizons. 18 (4): 263-286.

Ohlson, J. 1995. Earnings, book values and dividends in security valuation. Contemporary Accounting Research. 11: 661-687.

Rabier, M. 2018. Value is in the eye of the beholder: The relative valuation roles of earnings and book value in merger pricing. The Accounting Review. 93 (1): 335-362.

Rajan, R. and L. Zingales. 1995. What do we know about capital structure? Some evidence from international data. The Journal of Finance. 50 (5): 1421-1460.

Sen, S. and C. B. Bhattacharya. 2001. Does doing good always lead to doing better? Consumer reactions to corporate social responsibility. Journal of Marketing Research. 38 (2): 225243.

Shleifer, A. and R. Vishny. 1992. Liquidation values and debt capacity: A market equilibrium approach. The Journal of Finance. 47 (4): 1343-1366.

Siegel, M. 2017. For the investor: Should the FASB have a role in sustainability disclosures. Available at https://www.fasb.org/jsp/FASB/Page/SectionPage\&cid=1176163963376

Srivastava, A. 2014. Why have measures of earnings quality changed over time? Journal of Accounting and Economics. 57 (2-3): 196-217.

Szwajkowski, E. and R. Figlewicz. 1999. Evaluating corporate performance: A comparison of the Fortune reputation survey and the Socrates social ranking database. Journal of Managerial Issues. 11 (2): 137-154.

Waddock, S., and S. Graves. 1997. The corporate social performance - financial performance link. Strategic Management Journal. 18 (4): 303-319.

World Business Council for Sustainable Development (WBCSD). 2017. Sustainability and enterprise risk management: The first step towards integration. January 18. Available at https://docs.wbcsd.org/2017/01/WBCSD_Risk_Publication_2016.pdf

Wells, G. and J. D. McKinnion. 2018. Facebook data on 87 million users may have been improperly shared. The Wall Street Journal. April 4.

Williamson, O. 1988. Corporate finance and corporate governance. Journal of Finance. 43: 567592. 


\section{APPENDIX A \\ Discussion of Corporate Social Responsibility Dimensions}

MSCI KLD Analytics (KLD) provides the most comprehensive, publicly available corporate social responsibility ratings database. Over time, the KLD database has evolved to cover firms in the MSCI KLD 400 Social Index, MSCI USA Index, MSCI USA IMI Index, and the 1,000 largest US companies by market capitalization. KLD analysts annually review sample firms across the dimensions of product quality and safety, employee relations, environment, community, diversity, and human rights. In each of these dimensions, firms are rated in a binary fashion on many positive indicators ("strengths") and negative indicators ("concerns"). To rate these strengths and concerns, KLD analysts gather data from a wide range of resources including, but not limited to, company disclosures, government databases, and other stakeholder sources. KLD data has passed many reliability and validity tests (Swajkowski and Figlewicz 1999; Mattingly and Berman 2006) which, combined with its extensive multidimensional approach, have made KLD data one of the most widely used resources to operationalize the CSR construct. This appendix provides further discussion of the primary dimensions rated by KLD analysts.

\section{CSR DIMENSION DESCRIPTION}

\begin{tabular}{|l|l|}
\hline PRODUCT QUALITY & $\begin{array}{l}\text { The product dimension assesses how consumers are affected by the } \\
\text { company's product and actions. Example strength attributes } \\
\text { include proactively managing product quality, growth in healthier } \\
\text { products, chemical safety, and privacy and data security. Example } \\
\text { concern attributes include egregious instances of product recalls, } \\
\text { false advertising, anticompetitive practices, and customer related } \\
\text { legal cases. }\end{array}$ \\
\hline EMPLOYEE RELATIONS & $\begin{array}{l}\text { The employee dimension assesses the company's commitment and } \\
\text { effectiveness in supporting its employees. Main aspects of this } \\
\text { dimension are a commitment to employee rights and a focus on } \\
\text { health and safety. Example strength attributes include positive } \\
\text { union relations, employee profit sharing or stock purchase plans, } \\
\text { and strong health and safety programs. Example concern attributes } \\
\text { include unsafe work practices, child labor controversies, reduction } \\
\text { of benefits, and mistreatment of employees. }\end{array}$ \\
\hline ENVIRONMENT & $\begin{array}{l}\text { The environment dimension assesses the company's interactions } \\
\text { with the natural environment. Example strength attributes include } \\
\text { energy efficiency, green buildings, and programs to reduce toxic } \\
\text { emissions. Example concern attributes include toxic emissions, } \\
\text { severe water stress, and non-compliance with U.S. environmental } \\
\text { regulations. }\end{array}$ \\
\hline
\end{tabular}




\section{APPENDIX A \\ Discussion of Corporate Social Responsibility Dimensions \\ (continued)}

\begin{tabular}{|l|l|}
\hline COMMUNITY & $\begin{array}{l}\text { The community dimension assesses the company's commitment } \\
\text { and effectiveness in serving its community. Main aspects of this } \\
\text { dimension are corporate citizenship, charitable giving, and } \\
\text { volunteerism. Example strength attributes include charitable } \\
\text { giving programs, support for education, and volunteer programs. } \\
\text { Example concern attributes include tax disputes, land use disputes, } \\
\text { and other controversies with community opposition. }\end{array}$ \\
\hline DIVERSITY & $\begin{array}{l}\text { The diversity dimension assesses the company's commitment and } \\
\text { effectiveness in promoting diversity in their workforce and } \\
\text { leadership. Example strength attributes include employment of } \\
\text { underrepresented groups and gender diversity in the board of } \\
\text { directors or CEO. Example concern attributes include } \\
\text { discrimination related legal cases and the lack of women on the } \\
\text { board of directors. }\end{array}$ \\
\hline HUMAN RIGHTS & $\begin{array}{l}\text { The human rights dimension assesses the company's commitment } \\
\text { and effectiveness in supporting human rights. Main aspects of this } \\
\text { category are involvement with controversial regimes or sourcing } \\
\text { practices. Example strength attributes include respect for the land, } \\
\text { culture and rights of indigenous peoples, positive overseas sources, } \\
\text { and transparency on human rights issues. Example concern } \\
\text { attributes include support for controversial regimes, controversial } \\
\text { supply chain labor standards, and involvement in serious } \\
\text { controversies with indigenous peoples. }\end{array}$ \\
\hline
\end{tabular}




\title{
APPENDIX B \\ Variable Definitions
}

\begin{abstract}
Dependent Variable
PRICE $\quad=$ Firm's share price three months after the end of fiscal year $t$. (Source: CRSP)

Primary Independent Variables

\begin{tabular}{ll}
\hline EARN & $\begin{array}{l}\text { Net income before extraordinary items divided by total common } \\
\text { shares outstanding at end of fiscal year } t \text { (Source: } \text { Compustat) }\end{array}$ \\
$=$ & Book value of equity at end of fiscal year $t$ - 1 divided by total common \\
& shares outstanding at end of fiscal year $t$ (Source: Compustat) \\
$=$ & Equals one if the firm's CSR score is less than zero for year $t$, and \\
& $\begin{array}{l}\text { zero otherwise. CSR score is calculated as total strengths minus total } \\
\text { concerns across the MSCI KLD Analytics dimensions of product } \\
\text { quality and safety, employee relations, environment, community, } \\
\text { diversity, and human rights. (Source: MSCI KLD Analytics) }\end{array}$
\end{tabular}
\end{abstract}

Control Variables

\begin{tabular}{ll}
\hline LEVERAGE $=$ & Long term debt divided by total assets at end of fiscal year $t$ (Source: \\
& Compustat) \\
$=$ & Natural log of total assets at end of fiscal year $t$ (Source: Compustat) \\
SIZE
\end{tabular}

Partitioning Variables

TANGIBILITY = Current assets plus net property, plant and equipment, divided by total assets at end of fiscal year $t$ (Source: Compustat)

TANGIBILITY PPE = Net property, plant and equipment divided by total assets at end of fiscal year $t$ (Source: Compustat)

ROA = Net income before extraordinary items divided by total assets at the end of fiscal year $t$ (Source: Compustat)

Additional Measure of Adaptation Value

\begin{tabular}{|c|c|}
\hline \multirow[t]{3}{*}{ EXITVAL } & $\begin{array}{l}=\text { Calculated as the result of the following model, with the restriction } \\
\text { that EXITVAL } \geq 0\end{array}$ \\
\hline & $\begin{array}{l}\text { EXITVAL }_{t}=1.0 \text { Cash }_{t}+1.0 \text { Marketable Securities }_{t}+ \\
0.72 \text { Receivables }_{t}+0.55 \text { Inventory }_{t}+ \\
0.54 \text { Fixed Assets }_{t}-1.0 \text { Payables }_{t}-1.0 \text { Total Debt }_{t}\end{array}$ \\
\hline & (Source: Compustat) \\
\hline
\end{tabular}




\section{APPENDIX B \\ Variable Definitions \\ (continued)}

\section{Additional Measures of E\&S Risk}

\begin{tabular}{|c|c|}
\hline $\begin{array}{l}\text { E\&S RISK } \\
\text { CONCERNS }\end{array}$ & $\begin{array}{l}=\text { Equals one if the firm's total concerns across the MSCI KLD } \\
\text { Analytics dimensions of product quality and safety, employee } \\
\text { relations, environment, community, diversity, and human rights is } \\
\text { greater than the median concerns in a given year, and zero otherwise } \\
\text { (Source: MSCI KLD Analytics) }\end{array}$ \\
\hline $\begin{array}{l}\text { IND ADJ } \\
\text { E\&S RISK }\end{array}$ & $\begin{array}{l}=\text { Equals one if the firm's Industry Adjusted CSR Score is less than one, } \\
\text { and zero otherwise. Industry Adjusted CSR Score is equal to the } \\
\text { firm's CSR Score minus the industry-year median CSR Score. } \\
\text { (Source: MSCI KLD Analytics) }\end{array}$ \\
\hline $\begin{array}{c}\text { NORMALIZED } \\
\text { E\&S RISK }\end{array}$ & $\begin{array}{l}=\text { Equals one of the firm's normalized E\&S strengths minus normalized } \\
\text { E\&S concerns is negative, and zero otherwise. Normalized E\&S } \\
\text { strengths is equal to the sum of E\&S strengths divided by the number } \\
\text { of strengths in which the firm is rated. Normalized E\&S concerns is } \\
\text { equal to the sum of E\&S concerns divided by the number of concerns } \\
\text { in which the firm is rated. (Source: } M S C I \text { KLD Analytics) }\end{array}$ \\
\hline $\begin{array}{c}\text { CONTINUOUS } \\
\text { E\&S RISK }\end{array}$ & $\begin{array}{l}=\text { Equals the absolute value of CSR score when CSR score is negative, } \\
\text { and zero otherwise. CSR score is calculated as total strengths minus } \\
\text { total concerns across the MSCI KLD Analytics dimensions of } \\
\text { product quality and safety, employee relations, environment, } \\
\text { community, diversity, and human rights. (Source: MSCI KLD } \\
\text { Analytics) }\end{array}$ \\
\hline $\begin{array}{r}\text { CONT SQRT } \\
\text { E\&S RISK }\end{array}$ & $\begin{array}{l}=\text { Equals the square root of the absolute value of CSR score when CSR } \\
\text { score is negative, and zero otherwise. CSR score is calculated as } \\
\text { total strengths minus total concerns across the MSCI KLD Analytics } \\
\text { dimensions of product quality and safety, employee relations, } \\
\text { environment, community, diversity, and human rights. (Source: } \\
\text { MSCI KLD Analytics) }\end{array}$ \\
\hline ENV RISK & $\begin{array}{l}=\text { Equals one if the firm's environmental score is less than zero for year } \\
t \text {, and zero otherwise. Environmental score is calculated as total } \\
\text { strengths minus total concerns within the MSCI KLD Analytics } \\
\text { environment dimension. (Source: MSCI KLD Analytics) }\end{array}$ \\
\hline SOC RISK & $\begin{array}{l}=\text { Equals one if the firm's social score is less than zero for year } t \text {, and } \\
\text { zero otherwise. Social score is calculated as total strengths minus } \\
\text { total concerns across the MSCI KLD Analytics dimensions of } \\
\text { product quality and safety, employee relations, community, } \\
\text { diversity, and human rights. (Source: MSCI KLD Analytics) }\end{array}$ \\
\hline
\end{tabular}


TABLE 1

Sample Selection Procedures

Firm-year

Observations

$\mathrm{E} \& \mathrm{~S}$ RISK $=0^{\mathrm{a}} \quad \mathrm{E} \& S$ RISK $=1^{\mathrm{a}}$

\begin{tabular}{|c|c|c|c|}
\hline Total Firm-year observations rated for E\&S performance ${ }^{b}$ & 32,045 & 18,805 & 13,240 \\
\hline Less: Observations with negative income before extraordinary items ${ }^{c}$ & $(6,366)$ & $(3,412)$ & $(2,954)$ \\
\hline Less: Observations with negative book value ${ }^{\mathrm{d}}$ & $(777)$ & $(450)$ & $(327)$ \\
\hline Less: Observations with missing data to calculate all variables ${ }^{\mathrm{e}}$ & $(127)$ & $(80)$ & $(47)$ \\
\hline Final Sample & 24,775 & 14,863 & 9,912 \\
\hline
\end{tabular}

${ }^{a}$ E\&S RISK is equal to one for firms with a CSR score less than zero for year t, and zero otherwise. CSR score is calculated as total strengths minus total concerns across the MSCI KLD Analytics dimensions of product quality and safety, employee relations, environment, community, diversity, and human rights.

$\mathrm{b}$ The sample selection begins with all firm-years rated for environmental and social performance by MSCI KLD Analytics with an available linkage to Compustat. Appendix A describes the MSCI KLD Analytics ratings approach. The sample period covers the years 1995 through 2015.

${ }^{c}$ Observations with income before extraordinary items less than zero are eliminated because prior research has shown that loss firms are already priced with the expectation of liquidation or adaptation.

${ }^{\mathrm{d}}$ Observations with negative book value are eliminated because I use book value as a proxy for adaptation value and negative values have no economic meaning in the context of adaptation value.

${ }^{\mathrm{e}}$ I require observations to have available data on Compustat and CRSP to calculate all dependent and independent variables, including all control variables. Refer to Appendix B for details of data used in construction of all variables. 
TABLE 2

Descriptive Statistics

\begin{tabular}{|c|c|c|c|c|c|c|c|c|c|c|c|}
\hline \multirow[b]{2}{*}{ VARIABLE } & \multirow[b]{2}{*}{$\mathbf{N}$} & \multirow[b]{2}{*}{ MEAN } & \multirow[b]{2}{*}{ STD } & \multirow[b]{2}{*}{$\mathbf{P 2 5}$} & \multirow[b]{2}{*}{ P50 } & \multirow[b]{2}{*}{ P75 } & \multicolumn{2}{|c|}{ E\&S RISK = 0 } & \multicolumn{2}{|c|}{ E\&S RISK = 1} & \multirow[b]{2}{*}{ DIFFERENCE } \\
\hline & & & & & & & $\mathbf{N}$ & MEAN & $\mathbf{N}$ & MEAN & \\
\hline PRICE & 24,775 & 36.8839 & 27.2922 & 18.4600 & 30.0500 & 47.0625 & 14,863 & 39.8553 & 9,912 & 32.4284 & $7.4269 * * *$ \\
\hline$E A R N$ & 24,775 & 1.9988 & 1.8054 & 0.8042 & 1.5334 & 2.5772 & 14,863 & 2.1134 & 9,912 & 1.8269 & $0.2865 * * *$ \\
\hline$B V$ & 24,775 & 14.5942 & 11.2644 & 7.0910 & 11.8366 & 18.6333 & 14,863 & 11.6286 & 9,912 & 13.6567 & $-2.0281 * * *$ \\
\hline$E \& S R I S K$ & 24,775 & 0.4001 & 0.4899 & 0.0000 & 0.0000 & 1.0000 & & & & & \\
\hline LEVERAGE & 24,775 & 0.1740 & 0.1642 & 0.0214 & 0.1397 & 0.2809 & 14,863 & 0.1603 & 9,912 & 0.1785 & $-0.0182 * * *$ \\
\hline SIZE & 24,775 & 7.6763 & 1.6756 & 6.4661 & 7.5489 & 8.7099 & 14,863 & 1.7088 & 9,912 & 7.2896 & $-5.5808 * * *$ \\
\hline TANGIBILITY & 19,070 & 0.7235 & 0.2014 & 0.5912 & 0.7636 & 0.8868 & 11,180 & 0.7141 & 7,890 & 0.7368 & $-0.0227 * * *$ \\
\hline$R O A$ & 24,775 & 0.0615 & 0.0525 & 0.0211 & 0.0487 & 0.0859 & 14,863 & 0.0526 & 9,912 & 0.0611 & -0.0085 \\
\hline
\end{tabular}

This table presents descriptive statistics of all primary variables employed in my analyses. Appendix B provides detailed descriptions of the calculation of all variables. All continuous variables have been winsorized at the $1 \%$ and $99 \%$ levels.

$* * *, * *, *$ denote significance at the $1 \%, 5 \%$, and $10 \%$ levels, respectively. 
TABLE 3

Correlations

\begin{tabular}{|c|c|c|c|c|c|c|c|c|c|}
\hline & VARIABLE & 1 & 2 & 3 & 4 & 5 & 6 & 7 & 8 \\
\hline 1 & PRICE & & 0.7138 & 0.5522 & -0.1333 & 0.0248 & 0.3591 & -0.0679 & 0.1851 \\
\hline 2 & $E A R N$ & 0.7081 & & 0.6230 & -0.0778 & 0.0137 & 0.4103 & -0.0155 & 0.2539 \\
\hline 3 & $B V$ & 0.5252 & 0.5741 & & -0.0680 & -0.0082 & 0.4552 & -0.0488 & -0.2385 \\
\hline 4 & $E \& S R I S K$ & -0.1465 & -0.0958 & -0.0697 & & 0.0225 & -0.1885 & 0.0555 & -0.0060 \\
\hline 5 & LEVERAGE & 0.0821 & 0.0929 & 0.1015 & 0.0087 & & 0.2224 & -0.2326 & -0.2260 \\
\hline 6 & SIZE & 0.3996 & 0.4398 & 0.4800 & -0.1855 & 0.3305 & & -0.2010 & -0.2843 \\
\hline 7 & TANGIBILITY & -0.0711 & -0.0217 & -0.0472 & 0.0590 & -0.2211 & -0.2117 & & 0.1466 \\
\hline 8 & $R O A$ & 0.2334 & 0.3469 & -0.2645 & -0.0030 & -0.2119 & -0.2951 & 0.1256 & \\
\hline
\end{tabular}

This table presents the correlation matrix between all key variables employed in my analyses. Pearson correlations are presented in the upper-right cells and Spearman correlations are presented in the bottom-left cells. All correlations presented in bold text are statistically significant at the 0.05 level or lower. 
TABLE 4

Incremental Value Relevance of Earnings and Book Value

(1) PRICE $_{\mathrm{i}, \mathrm{t}}=\alpha_{0}+\alpha_{1}$ EARN $_{\mathrm{i}, \mathrm{t}}+\alpha_{2} \mathrm{BV}_{\mathrm{i}, \mathrm{t}-1}+\varepsilon$

(2) PRICE $_{i, t}=\beta_{0}+\beta_{1}$ EARN $_{i, t}+\varepsilon$

(3) PRICE $_{i, t}=\gamma_{0}+\gamma_{1}$ BV $_{i, t-1}+\varepsilon$

\begin{tabular}{|c|c|c|c|c|c|c|}
\hline \multicolumn{3}{|c|}{ Panel A: E\&S RISK = 0} & \multirow{2}{*}{\multicolumn{2}{|c|}{ Adjusted $\mathrm{R}^{2}$}} & \multirow[b]{2}{*}{$\begin{array}{c}(1)-(3) \\
\text { Incr. Earn }\end{array}$} & \multirow[b]{2}{*}{$\begin{array}{l}(1)-(2) \\
\text { Incr. BV }\end{array}$} \\
\hline Year & Observations & (1) & & & & \\
\hline 1995 & 264 & 0.519 & 0.472 & 0.398 & 0.121 & 0.047 \\
\hline 1996 & 277 & 0.559 & 0.558 & 0.269 & 0.290 & 0.001 \\
\hline 1997 & 281 & 0.559 & 0.555 & 0.328 & 0.231 & 0.004 \\
\hline 1998 & 287 & 0.299 & 0.285 & 0.044 & 0.255 & 0.014 \\
\hline 1999 & 307 & 0.166 & 0.166 & 0.030 & 0.136 & 0.000 \\
\hline 2000 & 263 & 0.345 & 0.347 & 0.146 & 0.199 & -0.002 \\
\hline 2001 & 458 & 0.390 & 0.374 & 0.172 & 0.218 & 0.016 \\
\hline 2002 & 482 & 0.409 & 0.400 & 0.201 & 0.208 & 0.009 \\
\hline 2003 & 1,128 & 0.586 & 0.579 & 0.338 & 0.248 & 0.007 \\
\hline 2004 & 977 & 0.521 & 0.492 & 0.323 & 0.198 & 0.029 \\
\hline 2005 & 870 & 0.534 & 0.521 & 0.332 & 0.202 & 0.013 \\
\hline 2006 & 826 & 0.549 & 0.542 & 0.338 & 0.211 & 0.007 \\
\hline 2007 & 796 & 0.526 & 0.525 & 0.255 & 0.271 & 0.001 \\
\hline 2008 & 711 & 0.442 & 0.431 & 0.182 & 0.260 & 0.011 \\
\hline 2009 & 698 & 0.595 & 0.551 & 0.332 & 0.263 & 0.044 \\
\hline 2010 & 618 & 0.564 & 0.555 & 0.278 & 0.286 & 0.009 \\
\hline 2011 & 658 & 0.572 & 0.571 & 0.226 & 0.346 & 0.001 \\
\hline 2012 & 1,218 & 0.547 & 0.535 & 0.268 & 0.279 & 0.012 \\
\hline 2013 & 1,003 & 0.542 & 0.534 & 0.265 & 0.277 & 0.008 \\
\hline 2014 & 1,399 & 0.563 & 0.557 & 0.290 & 0.273 & 0.006 \\
\hline 2015 & 1,342 & 0.524 & 0.508 & 0.249 & 0.275 & 0.016 \\
\hline Pooled & 14,863 & 0.525 & 0.515 & 0.275 & 0.250 & 0.010 \\
\hline
\end{tabular}


TABLE 4

Incremental Value Relevance of Earnings and Book Value (continued)

\begin{tabular}{|c|c|c|c|c|c|c|}
\hline \multicolumn{2}{|c|}{ Panel B: E\&S Risk = 1} & \multirow{2}{*}{\multicolumn{3}{|c|}{ Adjusted $\mathrm{R}^{2}$}} & \multirow[b]{2}{*}{$\begin{array}{c}(1)-(3) \\
\text { Incr. Earn }\end{array}$} & \multirow[b]{2}{*}{$\begin{array}{l}(1)-(2) \\
\text { Incr. BV }\end{array}$} \\
\hline Year & Observations & & & (3) & & \\
\hline 1995 & 90 & 0.406 & 0.387 & 0.261 & 0.145 & 0.019 \\
\hline 1996 & 87 & 0.641 & 0.620 & 0.427 & 0.214 & 0.021 \\
\hline 1997 & 82 & 0.577 & 0.582 & 0.328 & 0.249 & -0.005 \\
\hline 1998 & 83 & 0.226 & 0.168 & 0.188 & 0.038 & 0.058 \\
\hline 1999 & 108 & 0.137 & 0.145 & 0.040 & 0.097 & -0.008 \\
\hline 2000 & 91 & 0.216 & 0.218 & 0.112 & 0.104 & -0.002 \\
\hline 2001 & 147 & 0.309 & 0.213 & 0.240 & 0.069 & 0.096 \\
\hline 2002 & 216 & 0.572 & 0.499 & 0.340 & 0.232 & 0.073 \\
\hline 2003 & 652 & 0.599 & 0.540 & 0.433 & 0.166 & 0.059 \\
\hline 2004 & 914 & 0.658 & 0.615 & 0.453 & 0.205 & 0.043 \\
\hline 2005 & 881 & 0.551 & 0.511 & 0.391 & 0.160 & 0.040 \\
\hline 2006 & 894 & 0.536 & 0.512 & 0.361 & 0.175 & 0.024 \\
\hline 2007 & 819 & 0.534 & 0.516 & 0.286 & 0.248 & 0.018 \\
\hline 2008 & 697 & 0.496 & 0.422 & 0.343 & 0.153 & 0.074 \\
\hline 2009 & 671 & 0.615 & 0.566 & 0.345 & 0.270 & 0.049 \\
\hline 2010 & 1,065 & 0.544 & 0.502 & 0.323 & 0.221 & 0.042 \\
\hline 2011 & 1,006 & 0.592 & 0.557 & 0.373 & 0.219 & 0.035 \\
\hline 2012 & 451 & 0.576 & 0.534 & 0.390 & 0.186 & 0.042 \\
\hline 2013 & 593 & 0.558 & 0.533 & 0.378 & 0.180 & 0.025 \\
\hline 2014 & 120 & 0.531 & 0.466 & 0.384 & 0.147 & 0.065 \\
\hline 2015 & 245 & 0.495 & 0.466 & 0.358 & 0.137 & 0.029 \\
\hline Pooled & 9,912 & 0.537 & 0.495 & 0.358 & 0.179 & 0.042 \\
\hline
\end{tabular}


TABLE 4

Incremental Value Relevance of Earnings and Book Value (continued)

Panel C: Comparison of Firms by Presence of E\&S Risk

\begin{tabular}{|c|c|c|c|c|c|c|}
\hline \multirow{2}{*}{ Year } & \multicolumn{3}{|c|}{$\begin{array}{c}\text { Incremental Value Relevance } \\
\text { of Earnings }\end{array}$} & \multicolumn{3}{|c|}{$\begin{array}{c}\text { Incremental Value Relevance } \\
\text { of Book Value }\end{array}$} \\
\hline & $\begin{array}{c}E \& S \\
\text { Risk }=0\end{array}$ & $\begin{array}{c}E \& S \\
\text { Risk }=1\end{array}$ & Difference & $\begin{array}{c}E \& S \\
\text { Risk }=0\end{array}$ & $\begin{array}{c}E \& S \\
\text { Risk }=1\end{array}$ & Difference \\
\hline 1995 & 0.121 & 0.145 & -0.024 & 0.047 & 0.019 & 0.028 \\
\hline 1996 & 0.290 & 0.214 & 0.076 & 0.001 & 0.021 & -0.020 \\
\hline 1997 & 0.231 & 0.249 & -0.018 & 0.004 & -0.005 & 0.009 \\
\hline 1998 & 0.255 & 0.038 & 0.217 & 0.014 & 0.058 & -0.044 \\
\hline 1999 & 0.136 & 0.097 & 0.039 & 0.000 & -0.008 & 0.008 \\
\hline 2000 & 0.199 & 0.104 & 0.095 & -0.002 & -0.002 & 0.000 \\
\hline 2001 & 0.218 & 0.069 & 0.149 & 0.016 & 0.096 & -0.080 \\
\hline 2002 & 0.208 & 0.232 & -0.024 & 0.009 & 0.073 & -0.064 \\
\hline 2003 & 0.248 & 0.166 & 0.082 & 0.007 & 0.059 & -0.052 \\
\hline 2004 & 0.198 & 0.205 & -0.007 & 0.029 & 0.043 & -0.014 \\
\hline 2005 & 0.202 & 0.160 & 0.042 & 0.013 & 0.040 & -0.027 \\
\hline 2006 & 0.211 & 0.175 & 0.036 & 0.007 & 0.024 & -0.017 \\
\hline 2007 & 0.271 & 0.248 & 0.023 & 0.001 & 0.018 & -0.017 \\
\hline 2008 & 0.260 & 0.153 & 0.107 & 0.011 & 0.074 & -0.063 \\
\hline 2009 & 0.263 & 0.270 & -0.007 & 0.044 & 0.049 & -0.005 \\
\hline 2010 & 0.286 & 0.221 & 0.065 & 0.009 & 0.042 & -0.033 \\
\hline 2011 & 0.346 & 0.219 & 0.127 & 0.001 & 0.035 & -0.034 \\
\hline 2012 & 0.279 & 0.186 & 0.093 & 0.012 & 0.042 & -0.030 \\
\hline 2013 & 0.277 & 0.180 & 0.097 & 0.008 & 0.025 & -0.017 \\
\hline 2014 & 0.273 & 0.147 & 0.126 & 0.006 & 0.065 & -0.059 \\
\hline 2015 & 0.275 & 0.137 & 0.138 & 0.016 & 0.029 & -0.013 \\
\hline Pooled & 0.250 & 0.179 & 0.071 & 0.010 & 0.042 & -0.032 \\
\hline
\end{tabular}

Table 4 presents the Adjusted $\mathrm{R}^{2} \mathrm{~s}$ from estimating models (1), (2), and (3) separately for observations with $E \& S R I S K$ equal to zero (Panel A) and $E \& S$ RISK equal to one (Panel B). Adjusted $\mathrm{R}^{2} \mathrm{~s}$ from these models are used to calculate the incremental value relevance of earnings and book value. A comparison of these values is presented in a tabular format in Panel $\mathrm{C}$ and graphically in Figure 1. The dependent variable is the firm's share price three months after its fiscal year end $\left(P R I C E_{i, t}\right) . \quad B V_{i, t-1}$ is the book value per share of firm $i$ at the end of year $t-1$. $E A R N_{i, t}$ is the earnings before extraordinary items per share of firm $i$ for year $t$. Full definitions for all variables are provided in Appendix B. 
TABLE 5

E\&S Risk and the Value Relevance of Earnings and Book Value

\begin{tabular}{|c|c|c|}
\hline & (1) & (2) \\
\hline CONSTANT & $\begin{array}{l}13.500 * * * \\
(10.26)\end{array}$ & $\begin{array}{l}-3.138 \\
(-0.54)\end{array}$ \\
\hline EARN & $\begin{array}{l}7.225^{* * * *} \\
(25.71)\end{array}$ & $\begin{array}{l}7.747 * * * \\
(6.69)\end{array}$ \\
\hline$B V$ & $\begin{array}{l}0.506 * * * \\
(9.43)\end{array}$ & $\begin{array}{l}0.946^{* * *} \\
(4.22)\end{array}$ \\
\hline$E \& S$ RISK & $\begin{array}{l}0.600 \\
(0.95)\end{array}$ & $\begin{array}{l}1.090^{*} \\
(1.75)\end{array}$ \\
\hline$E \& S R I S K * E A R N$ & $\begin{array}{l}-1.714 * * * * \\
(-5.34)\end{array}$ & $\begin{array}{l}-1.687 * * * \\
(-5.25)\end{array}$ \\
\hline$E \& S R I S K * B V$ & $\begin{array}{l}\mathbf{0 . 1 8 4} * * * \\
(\mathbf{3 . 5 4})\end{array}$ & $\begin{array}{l}\mathbf{0 . 1 4 6 * * * *} \\
(\mathbf{2 . 8 5})\end{array}$ \\
\hline SIZE & & $\begin{array}{l}2.291 * * * * \\
(2.80)\end{array}$ \\
\hline$S I Z E * E A R N$ & & $\begin{array}{l}0.001 \\
(0.00)\end{array}$ \\
\hline$S I Z E * B V$ & & $\begin{array}{l}-0.062 * * \\
(-2.51)\end{array}$ \\
\hline LEVERAGE & & $\begin{array}{l}-1.154 \\
(-0.38)\end{array}$ \\
\hline$L E V E R A G E * E A R N$ & & $\begin{array}{l}-2.741 * * \\
(-2.03)\end{array}$ \\
\hline LEVERAGE *BV & & $\begin{array}{l}0.520^{* * *} \\
(2.14)\end{array}$ \\
\hline Year FE & Yes & Yes \\
\hline Firm FE & Yes & Yes \\
\hline Observations & 24,775 & 24,775 \\
\hline Adjusted $R^{2}$ & 0.767 & 0.768 \\
\hline
\end{tabular}

Table 5 presents the results of estimating models (4) and (5) as a test of H1 and H2. Column 1 presents results of the base model without including control variables and Column 2 presents the results of the full model including control variables. The dependent variable is the firm's share price three months after its fiscal year end $\left(P R I C E_{i, t}\right)$. Full definitions for all variables are provided in Appendix B. Standard errors are clustered by firm.

$* * *, * *, *$ denote significance at the $1 \%, 5 \%$, and $10 \%$ levels, respectively. 
TABLE 6

Examination of the Role of Asset Tangibility

\begin{tabular}{|c|c|c|c|c|}
\hline \multicolumn{5}{|c|}{ Panel A: Partitioning variable $=$ TANGIBILITY } \\
\hline & (1) & $(2)$ & (3) & (4) \\
\hline & Low & High & Low & High \\
\hline & Tangibility & Tangibility & Tangibility & Tangibility \\
\hline CONSTANT & $\begin{array}{c}14.570 * * * \\
(7.45)\end{array}$ & $\begin{array}{c}12.970 * * * \\
(6.61)\end{array}$ & $\begin{array}{l}9.532 \\
(1.11)\end{array}$ & $\begin{array}{r}-12.560 \\
(-1.18)\end{array}$ \\
\hline$E A R N$ & $\begin{array}{l}7.776^{* * * *} \\
(16.51)\end{array}$ & $\begin{array}{l}7.116 * * * \\
(14.62)\end{array}$ & $\begin{array}{l}9.853 * * * \\
(4.89)\end{array}$ & $\begin{array}{l}7.881 * * * \\
(3.56)\end{array}$ \\
\hline$B V$ & $\begin{array}{l}0.548 * * * \\
(680)\end{array}$ & $\begin{array}{l}0.493 * * * \\
(454)\end{array}$ & $0.612 *$ & $\begin{array}{l}0.403 \\
(0.94)\end{array}$ \\
\hline$E \& S R I S K$ & $2.124 * *$ & 0.320 & $2.358 * *$ & 0.578 \\
\hline$E \& S R I S K * E A R N$ & $-1.769 * * *$ & $-2.018 * * *$ & $-1.843 * * *$ & $-2.087 * * *$ \\
\hline$E \& S R I S K * B V$ & $\begin{array}{l}0.110 \\
(1.27)\end{array}$ & $\begin{array}{l}\text { 0.245**** } \\
(2.70)\end{array}$ & $\begin{array}{l}0.105 \\
(1.23)\end{array}$ & $\begin{array}{l}0.228 * * * \\
(2.63)\end{array}$ \\
\hline SIZE & & & $\begin{array}{l}0.672 \\
(0.56)\end{array}$ & $\begin{array}{l}4.234 * * \\
(2.50)\end{array}$ \\
\hline$S I Z E * E A R N$ & & & $\begin{array}{l}-0.136 \\
(-0.62)\end{array}$ & $\begin{array}{l}-0.040 \\
(-0.14)\end{array}$ \\
\hline$S I Z E * B V$ & & & $\begin{array}{l}-0.020 \\
(-0.55)\end{array}$ & $\begin{array}{l}-0.002 \\
(-0.03)\end{array}$ \\
\hline LEVERAGE & & & $\begin{array}{l}-2.028 \\
(-0.38)\end{array}$ & $\begin{array}{l}1.929 \\
(0.30)\end{array}$ \\
\hline LEVERAGE * EARN & & & $\begin{array}{l}-3.917 * \\
(-1.72)\end{array}$ & $\begin{array}{l}-3.267 \\
(-1.26)\end{array}$ \\
\hline$L E V E R A G E * B V$ & & & $\begin{array}{l}0.437 \\
(1.09)\end{array}$ & $\begin{array}{l}0.120 \\
(0.24)\end{array}$ \\
\hline Year FE & Yes & Yes & Yes & Yes \\
\hline Firm FE & Yes & Yes & Yes & Yes \\
\hline Observations & 9,629 & 9,441 & 9,629 & 9,441 \\
\hline Adjusted $R^{2}$ & 0.775 & 0.754 & 0.775 & 0.756 \\
\hline
\end{tabular}


TABLE 6

Examination of the Role of Asset Tangibility

(continued)

\begin{tabular}{|c|c|c|c|c|}
\hline \multicolumn{5}{|c|}{ Panel B: Partitioning variable $=$ TANGIBILITY PPE } \\
\hline & (1) & (2) & (3) & (4) \\
\hline & Low & High & Low & High \\
\hline & Tangibility & Tangibility & Tangibility & Tangibility \\
\hline CONSTANT & $\begin{array}{c}14.010 * * * \\
(7.07)\end{array}$ & $\begin{array}{c}12.500 * * * \\
(6.25)\end{array}$ & $\begin{array}{l}-0.865 \\
(-0.11)\end{array}$ & $\begin{array}{l}-0.449 \\
(-0.05)\end{array}$ \\
\hline$E A R N$ & $\begin{array}{l}\text { 7.218**** } \\
(16.48)\end{array}$ & $\begin{array}{l}7.228 * * * \\
(18.86)\end{array}$ & $\begin{array}{l}8.048 * * * \\
(5.46)\end{array}$ & $\begin{array}{l}6.714 * * * \\
(3.85)\end{array}$ \\
\hline$B V$ & $\begin{array}{l}0.481 \text { *** } \\
(7.16)\end{array}$ & $\begin{array}{l}0.521 \text { *** } \\
(5.49)\end{array}$ & $\begin{array}{l}1.027 * * * \\
(3.73)\end{array}$ & $\begin{array}{l}0.909^{* *} \\
(2.29)\end{array}$ \\
\hline$E \& S R I S K$ & $\begin{array}{l}1.375 \\
(1.63)\end{array}$ & $\begin{array}{l}-0.541 \\
(-0.54)\end{array}$ & $\begin{array}{l}1.860^{* *} \\
(2.24)\end{array}$ & $\begin{array}{l}-0.269 \\
(-0.28)\end{array}$ \\
\hline$E \& S R I S K * E A R N$ & $\begin{array}{l}-1.796 * * * * \\
(-3.95)\end{array}$ & $\begin{array}{l}-1.495 * * * \\
(-3.13)\end{array}$ & $\begin{array}{l}-1.815^{* * * *} \\
(-3.94)\end{array}$ & $\begin{array}{l}-1.312 * * * \\
(-2.77)\end{array}$ \\
\hline$E \& S R I S K * B V$ & $\begin{array}{l}0.137^{*} \\
(1.90)\end{array}$ & $\begin{array}{l}0.234 * * * \\
(2.95)\end{array}$ & $\begin{array}{l}0.107 \\
(1.48)\end{array}$ & $\begin{array}{l}0.190 * * \\
(2.48)\end{array}$ \\
\hline SIZE & & & $\begin{array}{l}2.016^{*} \\
(1.86)\end{array}$ & $\begin{array}{l}1.783 \\
(1.28)\end{array}$ \\
\hline$S I Z E * E A R N$ & & & $\begin{array}{l}-0.078 \\
(-0.50)\end{array}$ & $\begin{array}{l}0.161 \\
(0.81)\end{array}$ \\
\hline$S I Z E * B V$ & & & $\begin{array}{l}-0.068 * * \\
(-2.31)\end{array}$ & $\begin{array}{l}-0.060 \\
(-1.26)\end{array}$ \\
\hline LEVERAGE & & & $\begin{array}{l}-2.402 \\
(-0.56)\end{array}$ & $\begin{array}{l}0.956 \\
(0.19)\end{array}$ \\
\hline LEVERAGE *EARN & & & $\begin{array}{l}-0.657 \\
(-0.34)\end{array}$ & $\begin{array}{l}-4.625 * * \\
(-2.33)\end{array}$ \\
\hline LEVERAGE *BV & & & $\begin{array}{l}0.301 \\
(0.95)\end{array}$ & $\begin{array}{l}0.613 \\
(1.43)\end{array}$ \\
\hline Year FE & Yes & Yes & Yes & Yes \\
\hline Firm FE & Yes & Yes & Yes & Yes \\
\hline Observations & 11,936 & 11,737 & 11,936 & 11,737 \\
\hline Adjusted $R^{2}$ & 0.783 & 0.767 & 0.784 & 0.769 \\
\hline
\end{tabular}

Table 6 presents the results of estimating models (4) and (5) after partitioning the sample at the industry-year median asset tangibility. TANGIBILITY is the partitioning variable in Panel A and TANGIBILITY PPE is the partitioning variable in Panel B. The dependent variable is the firm's share price three months after its fiscal year end $\left(P R I C E_{i, t}\right)$. Full definitions for all variables are provided in Appendix B. Standard errors are clustered by firm. $* * *, * *, *$ denote significance at the $1 \%, 5 \%$, and $10 \%$ levels, respectively. 
TABLE 7

Cross Sectional Analysis: Financial Performance

\begin{tabular}{|c|c|c|c|c|}
\hline & $\begin{array}{c}(1) \\
\text { LOW ROA }\end{array}$ & $\begin{array}{c}\text { (2) } \\
\text { HIGH ROA }\end{array}$ & $\begin{array}{c}(3) \\
\text { LOW ROA }\end{array}$ & $\begin{array}{c}(4) \\
\text { HIGH ROA }\end{array}$ \\
\hline CONSTANT & $\begin{array}{c}12.610^{* * * *} \\
(6.53)\end{array}$ & $\begin{array}{c}13.990^{* * *} \\
(7.08)\end{array}$ & $\begin{array}{c}-21.650 * * * \\
(-2.58)\end{array}$ & $\begin{array}{c}18.130^{* * *} \\
(2.21)\end{array}$ \\
\hline$E A R N$ & $\begin{array}{l}\text { 7.114*** } \\
(15.19)\end{array}$ & $\begin{array}{l}8.825^{* * *} \\
(19.93)\end{array}$ & $\begin{array}{l}7.444 * * * \\
(3.51)\end{array}$ & $\begin{array}{l}7.597 * * * \\
(4.40)\end{array}$ \\
\hline$B V$ & $\begin{array}{l}0.408 * * * \\
(5.71)\end{array}$ & $\begin{array}{l}0.389 * * * \\
(4.58)\end{array}$ & $\begin{array}{l}0.860 * * * \\
(2.82)\end{array}$ & $\begin{array}{l}1.111^{* * *} \\
(3.08)\end{array}$ \\
\hline$E \& S R I S K$ & $\begin{array}{l}-0.112 \\
(-0.13)\end{array}$ & $\begin{array}{l}1.393 \\
(1.49)\end{array}$ & $\begin{array}{l}0.435 \\
(0.52)\end{array}$ & $\begin{array}{l}1.699 * \\
(1.83)\end{array}$ \\
\hline$E \& S$ RISK * EARN & $\begin{array}{l}-0.818 \\
(-1.57)\end{array}$ & $\begin{array}{l}-2.696 * * * \\
(-5.17)\end{array}$ & $\begin{array}{l}-0.851 \\
(-1.60)\end{array}$ & $\begin{array}{l}-2.623 * * * \\
(-5.03)\end{array}$ \\
\hline$E \& S R I S K * B V$ & $\begin{array}{l}\text { 0.092 } \\
(1.31)\end{array}$ & $\begin{array}{l}0.346 * * * \\
(4.08)\end{array}$ & $\begin{array}{l}\mathbf{0 . 0 5 8} \\
(\mathbf{0 . 8 4})\end{array}$ & $\begin{array}{l}0.312 * * * \\
(3.74)\end{array}$ \\
\hline SIZE & & & $\begin{array}{l}4.734 * * * \\
(4.24)\end{array}$ & $\begin{array}{l}-0.884 \\
(-0.74)\end{array}$ \\
\hline$S I Z E * E A R N$ & & & $\begin{array}{l}-0.041 \\
(-0.20)\end{array}$ & $\begin{array}{l}0.231 \\
(1.18)\end{array}$ \\
\hline$S I Z E * B V$ & & & $\begin{array}{l}-0.058^{*} \\
(-1.90)\end{array}$ & $\begin{array}{l}-0.098^{* *} \\
(-2.33)\end{array}$ \\
\hline LEVERAGE & & & $\begin{array}{l}-0.952 \\
(-0.22)\end{array}$ & $\begin{array}{l}-4.645 \\
(-0.93)\end{array}$ \\
\hline LEVERAGE * EARN & & & $\begin{array}{l}-0.126 \\
(-0.05)\end{array}$ & $\begin{array}{l}-3.591 \\
(-1.60)\end{array}$ \\
\hline LEVERAGE * BV & & & $\begin{array}{l}0.153 \\
(0.44)\end{array}$ & $\begin{array}{l}0.921 * * \\
(2.29)\end{array}$ \\
\hline Year FE & Yes & Yes & Yes & Yes \\
\hline Firm FE & Yes & Yes & Yes & Yes \\
\hline Observations & 12,293 & 12,482 & 12,293 & 12,482 \\
\hline Adjusted $R^{2}$ & 0.782 & 0.769 & 0.785 & 0.771 \\
\hline
\end{tabular}

Table 7 presents the results of estimating models (4) and (5) after partitioning the sample on the industry-year median return on assets $(R O A)$. The dependent variable is the firm's share price three months after its fiscal year end $\left(P R I C E_{i, t}\right)$. Full definitions for all variables are provided in Appendix B. Standard errors are clustered by firm.

$* * *, * *, *$ denote significance at the $1 \%, 5 \%$, and $10 \%$ levels, respectively. 
TABLE 8

Alternate Measure of Adaptation Value: Exit Value

\begin{tabular}{|c|c|c|}
\hline & (1) & (2) \\
\hline CONSTANT & $\begin{array}{l}17.300 * * * \\
(13.29)\end{array}$ & $\begin{array}{c}-14.170 * * \\
(2.45)\end{array}$ \\
\hline$E A R N$ & $\begin{array}{l}7.499 * * * \\
(26.52)\end{array}$ & $\begin{array}{l}6.009 * * * \\
(5.04)\end{array}$ \\
\hline EXIT VAL & $\begin{array}{l}0.493 * * * \\
(6.21)\end{array}$ & $\begin{array}{l}1.491 * * * \\
(4.36)\end{array}$ \\
\hline$E \& S R I S K$ & $\begin{array}{l}2.386 * * * \\
(4.52)\end{array}$ & $\begin{array}{l}2.469 * * * \\
(4.77)\end{array}$ \\
\hline$E \& S R I S K * E A R N$ & $\begin{array}{l}-1.643 * * * \\
(-5.57)\end{array}$ & $\begin{array}{l}-1.618 * * * \\
(-5.52)\end{array}$ \\
\hline$E \& S R I S K * E X I T V A L$ & $\begin{array}{l}0.169 * * * \\
(2.66)\end{array}$ & $\begin{array}{l}0.128 * * \\
(2.03)\end{array}$ \\
\hline SIZE & & $\begin{array}{l}4.526 * * * \\
(5.62)\end{array}$ \\
\hline$S I Z E * E A R N$ & & $\begin{array}{l}0.159 \\
(1.24)\end{array}$ \\
\hline$S I Z E * E X I T V A L$ & & $\begin{array}{l}-0.118 * * * \\
(-3.34)\end{array}$ \\
\hline LEVERAGE & & $\begin{array}{l}4.329 \\
(1.54)\end{array}$ \\
\hline$L E V E R A G E * E A R N$ & & $\begin{array}{l}-0.725 \\
(-0.58)\end{array}$ \\
\hline LEVERAGE * EXIT VAL & & $\begin{array}{l}0.803 \\
(1.57)\end{array}$ \\
\hline Year FE & Yes & Yes \\
\hline Firm FE & Yes & Yes \\
\hline Observations & 24,775 & 24,775 \\
\hline Adjusted $R^{2}$ & 0.759 & 0.762 \\
\hline
\end{tabular}

Table 8 presents the results of estimating models (4) and (5) when using exit value (EXITVAL), as calculated by Berger et al. (1996), as an alternate proxy for adaptation value. The dependent variable is the firm's share price three months after its fiscal year end $\left(P R I C E_{i, t}\right)$. Full definitions for all variables are provided in Appendix B. Standard errors are clustered by firm. $* * *, * *, *$ denote significance at the $1 \%, 5 \%$, and $10 \%$ levels, respectively. 
TABLE 9

Alternate Measures of Environmental and Social Risk

\begin{tabular}{|c|c|c|c|c|c|c|}
\hline & \multicolumn{2}{|c|}{ High Concerns } & \multicolumn{2}{|c|}{ Industry Adjusted } & \multicolumn{2}{|c|}{ Normalized } \\
\hline & (1) & (2) & (3) & (4) & (5) & (6) \\
\hline CONSTANT & $\begin{array}{l}13.670 * * * \\
(10.39)\end{array}$ & $\begin{array}{l}-1.783 \\
(-0.31)\end{array}$ & $\begin{array}{l}13.800 * * * \\
(10.55)\end{array}$ & $\begin{array}{l}-1.843 \\
(-0.32)\end{array}$ & $\begin{array}{l}13.450 * * * \\
(10.24)\end{array}$ & $\begin{array}{l}-3.752 \\
(-0.64)\end{array}$ \\
\hline$E A R N$ & $\begin{array}{l}6.988 * * * \\
(24.80)\end{array}$ & $\begin{array}{l}5.934 * * * \\
(5.22)\end{array}$ & $\begin{array}{l}7.001 * * * \\
(25.94)\end{array}$ & $\begin{array}{l}6.980 * * * \\
(6.17)\end{array}$ & $\begin{array}{l}7.415^{* * * *} \\
(24.68)\end{array}$ & $\begin{array}{l}8.084 * * * \\
(7.01)\end{array}$ \\
\hline$B V$ & $\begin{array}{l}0.520 * * * \\
(10.56)\end{array}$ & $\begin{array}{l}1.158 * * * \\
(5.32)\end{array}$ & $\begin{array}{l}0.525^{* * *} \\
(10.16)\end{array}$ & $\begin{array}{l}1.017 * * * \\
(4.59)\end{array}$ & $\begin{array}{l}0.495 * * * \\
(8.87)\end{array}$ & $\begin{array}{l}0.959 * * * \\
(4.32)\end{array}$ \\
\hline$E \& S R I S K$ & $\begin{array}{l}-0.810 \\
(-1.12)\end{array}$ & $\begin{array}{l}-1.285 \\
(-1.79)\end{array}$ & $\begin{array}{l}0.170 \\
(0.29)\end{array}$ & $\begin{array}{l}0.501 \\
(0.85)\end{array}$ & $\begin{array}{l}0.912 \\
(1.51)\end{array}$ & $\begin{array}{l}1.430 * * \\
(2.46)\end{array}$ \\
\hline$E \& S R I S K * E A R N$ & $\begin{array}{l}-0.918 * * * \\
(-2.67)\end{array}$ & $\begin{array}{l}-1.024 * * * \\
(-2.89)\end{array}$ & $\begin{array}{l}-1.356 * * * \\
(-4.01)\end{array}$ & $\begin{array}{l}-1.339 * * * * \\
(-4.00)\end{array}$ & $\begin{array}{l}-1.881 * * * \\
(-5.92)\end{array}$ & $\begin{array}{l}-1.899 * * * \\
(-6.06)\end{array}$ \\
\hline$E \& S R I S K * B V$ & $\begin{array}{l}0.138 * * \\
(2.56)\end{array}$ & $\begin{array}{l}0.178 * * * * \\
(3.17)\end{array}$ & $\begin{array}{l}0.170 * * * \\
(3.32)\end{array}$ & $\begin{array}{l}0.142 * * * \\
(2.81)\end{array}$ & $\begin{array}{l}0.175 * * * \\
(3.50)\end{array}$ & $\begin{array}{l}0.138 * * * \\
(2.85)\end{array}$ \\
\hline SIZE & & $\begin{array}{l}2.151 * * * \\
(2.62)\end{array}$ & & $\begin{array}{l}2.163 * * * \\
(2.64)\end{array}$ & & $\begin{array}{l}2.359 * * * \\
(2.88)\end{array}$ \\
\hline$S I Z E * E A R N$ & & $\begin{array}{l}0.188 \\
(1.44)\end{array}$ & & $\begin{array}{l}0.066 \\
(0.53)\end{array}$ & & $\begin{array}{l}-0.010 \\
(-0.08)\end{array}$ \\
\hline$S I Z E * B V$ & & $\begin{array}{l}-0.088 * * * \\
(-3.56)\end{array}$ & & $\begin{array}{l}-0.069 * * * \\
(-2.80)\end{array}$ & & $\begin{array}{l}-0.065 * * * \\
(-2.67)\end{array}$ \\
\hline$L E V E R A G E$ & & $\begin{array}{l}-0.561 \\
(-0.18)\end{array}$ & & $\begin{array}{l}-1.144 \\
(-0.37)\end{array}$ & & $\begin{array}{l}-1.248 \\
(-0.41)\end{array}$ \\
\hline
\end{tabular}


TABLE 9

Alternate Measures of Environmental and Social Risk

(continued)

\begin{tabular}{|c|c|c|c|c|c|c|}
\hline$L E V E R A G E * E A R N$ & & $\begin{array}{c}-2.641 * \\
(-1.94)\end{array}$ & & $\begin{array}{l}-2.783 * * \\
(-2.06)\end{array}$ & & $\begin{array}{l}-2.944 * * \\
(-2.19)\end{array}$ \\
\hline$L E V E R A G E * B V$ & & $\begin{array}{l}0.500 * * \\
(2.05)\end{array}$ & & $\begin{array}{l}0.542 * * \\
(2.21)\end{array}$ & & $\begin{array}{l}0.537 * * \\
(2.20)\end{array}$ \\
\hline Year FE & Yes & Yes & Yes & Yes & Yes & Yes \\
\hline Firm FE & Yes & Yes & Yes & Yes & Yes & Yes \\
\hline Observations & 24,775 & 24,775 & 24,775 & 24,775 & 24,775 & 24,775 \\
\hline Adjusted $R^{2}$ & 0.766 & 0.767 & 0.766 & 0.767 & 0.767 & 0.769 \\
\hline
\end{tabular}

Table 9 presents the results of estimating models (4) and (5) using various alternate measures of E\&S risk. In columns (1) and (2) E\&S risk equals E\&S RISK CONCERNS. In columns (3) and (4) E\&S risk equals IND ADJ E\&S RISK. In columns (5) and (6) E\&S risk equals NORMALIZED E\&S RISK. The dependent variable is the firm's share price three months after its fiscal year end $\left(P R I C E_{i, t}\right)$. Full definitions for all variables are provided in Appendix B. Standard errors are clustered by firm.

$* * *, * *, *$ denote significance at the $1 \%, 5 \%$, and $10 \%$ levels, respectively. 


\section{TABLE 10}

\section{Continuous Measures of Environmental and Social Risk}

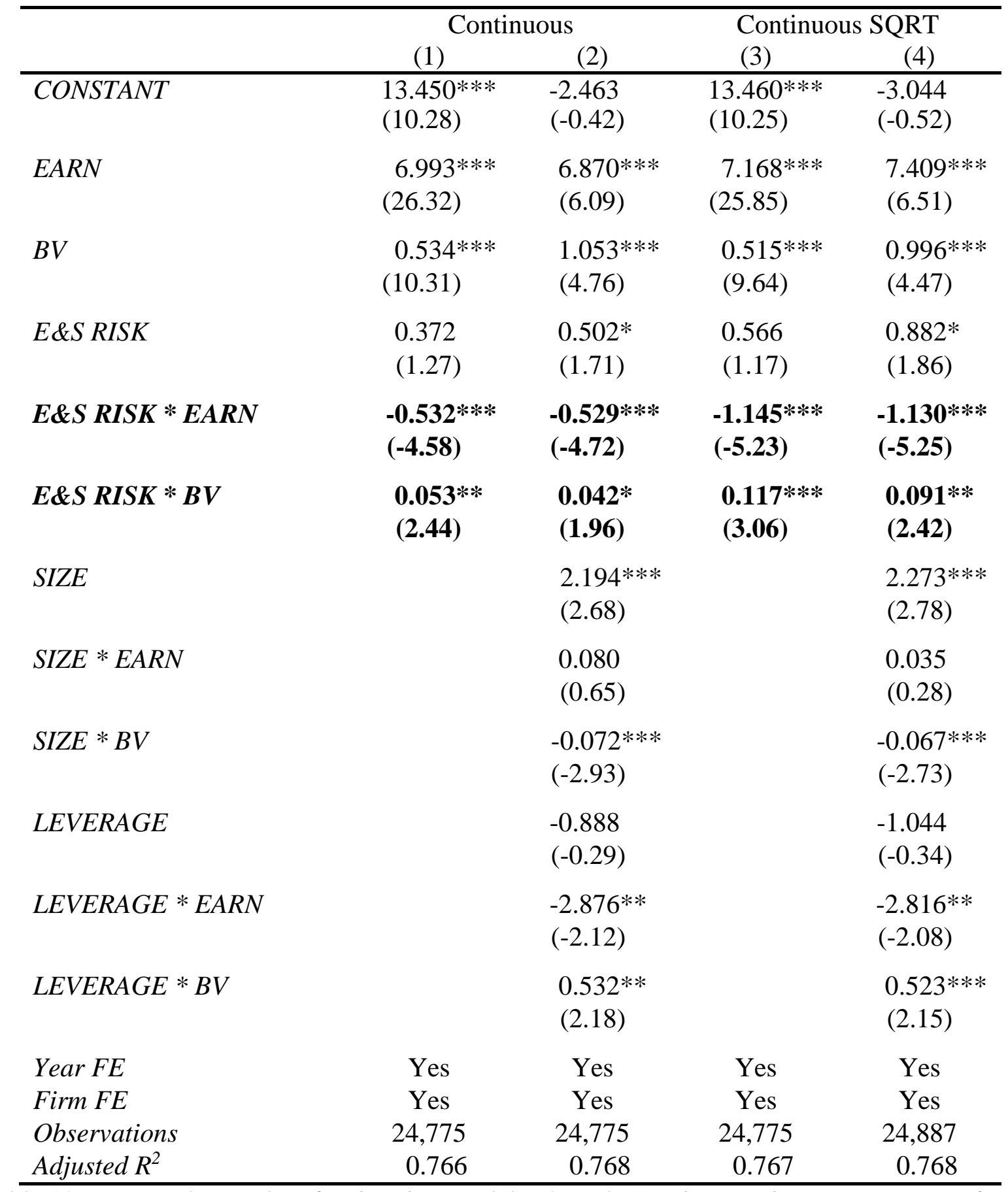

Table 10 presents the results of estimating models (4) and (5) using continuous measures of E\&S risk. In columns (1) and (2) E\&S risk equals CONTINUOUS E\&S RISK. In columns (3) and (4) E\&S risk equals CONT SQRT E\&S RISK. The dependent variable is the firm's share price three months after its fiscal year end $\left(P R I C E_{i, t}\right)$. Full definitions for all variables are provided in Appendix B. Standard errors are clustered by firm. $* * *, * *, *$ denote significance at the $1 \%, 5 \%$, and $10 \%$ levels, respectively. 
TABLE 11

Disaggregated Environmental and Social Risk

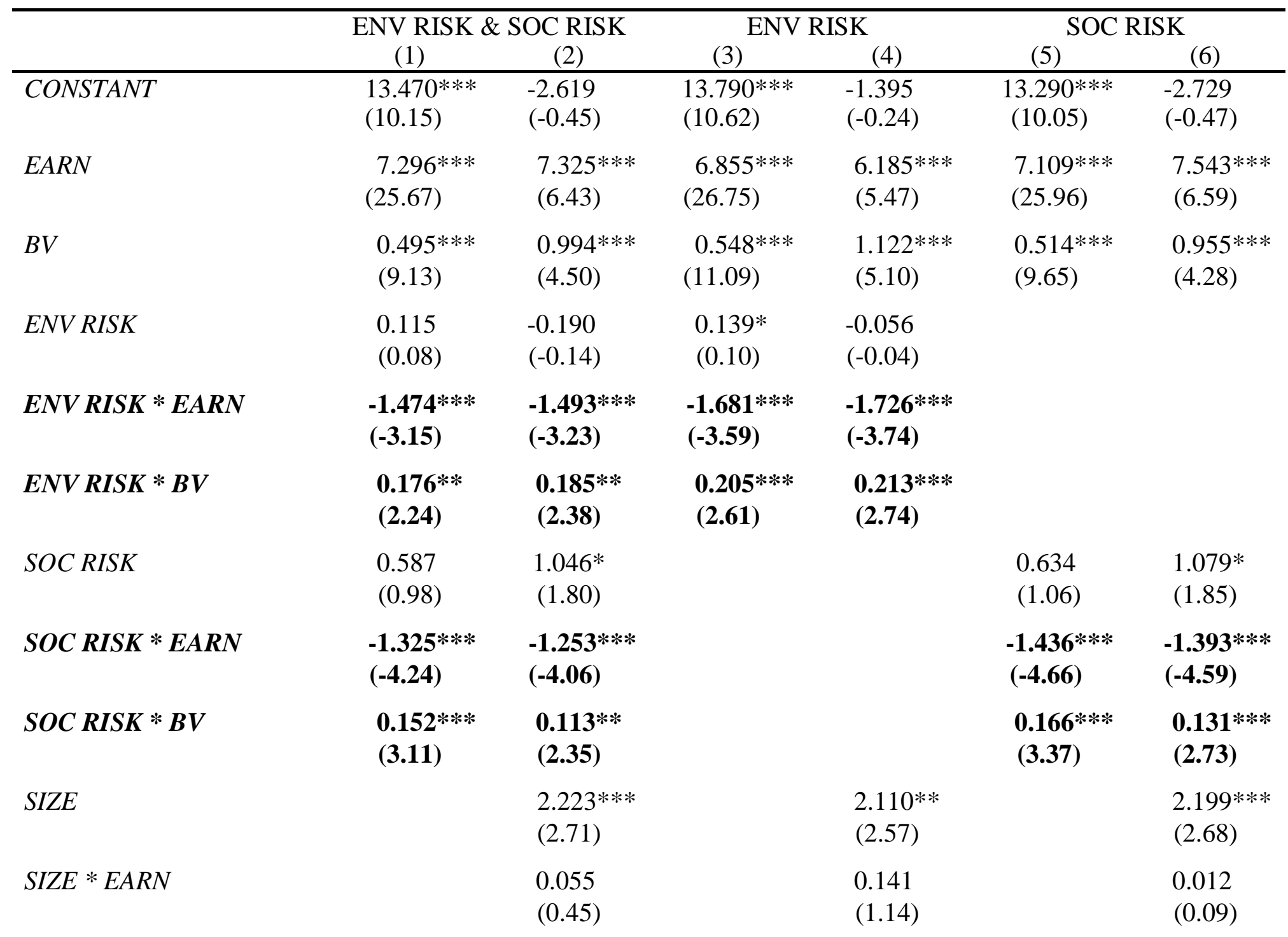


TABLE 11

Disaggregated Environmental and Social Risk

(continued)

\begin{tabular}{|c|c|c|c|c|c|c|}
\hline$S I Z E * B V$ & & $\begin{array}{l}-0.069 * * * \\
(-2.81)\end{array}$ & & $\begin{array}{l}-0.079 * * * \\
(-3.20)\end{array}$ & & $\begin{array}{l}0.063 * * \\
(-2.53)\end{array}$ \\
\hline LEVERAGE & & $\begin{array}{l}-1.217 \\
(-0.40)\end{array}$ & & $\begin{array}{l}-1.026 \\
(-0.33)\end{array}$ & & $\begin{array}{l}-0.992 \\
(-0.33)\end{array}$ \\
\hline LEVERAGE * EARN & & $\begin{array}{l}-2.701 * * \\
(-2.00)\end{array}$ & & $\begin{array}{l}-2.730 * * \\
(-2.00)\end{array}$ & & $\begin{array}{l}-2.791 * * \\
(-2.07)\end{array}$ \\
\hline$L E V E R A G E * B V$ & & $\begin{array}{l}0.504^{* *} \\
(2.07)\end{array}$ & & $\begin{array}{l}0.516^{* * *} \\
(2.12)\end{array}$ & & $\begin{array}{l}0.530^{* *} \\
(2.18)\end{array}$ \\
\hline Year FE & Yes & Yes & Yes & Yes & Yes & Yes \\
\hline Firm FE & Yes & Yes & Yes & Yes & Yes & Yes \\
\hline Observations & 24,775 & 24,775 & 24,775 & 24,775 & 24,775 & 24,775 \\
\hline Adjusted $R^{2}$ & 0.767 & 0.768 & 0.766 & 0.767 & 0.766 & 0.768 \\
\hline
\end{tabular}


TABLE 12

Sensitivity to Exclusion of Neutral Firms

\begin{tabular}{|c|c|c|}
\hline & (1) & (2) \\
\hline CONSTANT & $\begin{array}{l}14.340^{* * * *} \\
(10.08)\end{array}$ & $\begin{array}{l}-2.622 \\
(-0.41)\end{array}$ \\
\hline$E A R N$ & $\begin{array}{l}7.145^{* * *} \\
(22.57)\end{array}$ & $\begin{array}{l}7.356 * * * \\
(5.72)\end{array}$ \\
\hline$B V$ & $\begin{array}{l}0.499 * * * \\
(8.01)\end{array}$ & $\begin{array}{l}1.090 * * * \\
(4.38)\end{array}$ \\
\hline$E \& S R I S K$ & $\begin{array}{l}0.208 \\
(0.28)\end{array}$ & $\begin{array}{l}0.996 \\
(1.37)\end{array}$ \\
\hline$E \& S R I S K$ * EARN & $\begin{array}{l}-1.668 * * * \\
(-4.76)\end{array}$ & $\begin{array}{l}-1.589 * * * * \\
(-4.46)\end{array}$ \\
\hline$E \& S R I S K * B V$ & $\begin{array}{l}\text { 0.181**** } \\
(\mathbf{3 . 0 4 )}\end{array}$ & $\begin{array}{l}0.117 * * \\
(1.98)\end{array}$ \\
\hline SIZE & & $\begin{array}{l}2.269 * * * \\
(2.58)\end{array}$ \\
\hline$S I Z E * E A R N$ & & $\begin{array}{l}0.026 \\
(0.20)\end{array}$ \\
\hline$S I Z E * B V$ & & $\begin{array}{l}-0.078 * * * \\
(-2.91)\end{array}$ \\
\hline LEVERAGE & & $\begin{array}{l}-2.576 \\
(-0.77)\end{array}$ \\
\hline$L E V E R A G E * E A R N$ & & $\begin{array}{l}-2.392 \\
(-1.60)\end{array}$ \\
\hline LEVERAGE *BV & & $\begin{array}{l}0.602 * * \\
(2.24)\end{array}$ \\
\hline Year FE & Yes & Yes \\
\hline Firm FE & Yes & Yes \\
\hline Observations & 21,490 & 21,490 \\
\hline Adjusted $R^{2}$ & 0.767 & 0.768 \\
\hline
\end{tabular}

Table 12 presents the results of estimating models (4) and (5) when adjusting the sample to exclude neutral firms. For the purpose of this test, neutral firms are firm-year observations that do not receive a 1-rating in any strength or concern attribute. The dependent variable is the firm's share price three months after its fiscal year end $\left(P R I C E_{i, t}\right)$. Full definitions for all variables are provided in Appendix B. Standard errors are clustered by firm.

$* * *, * *, *$ denote significance at the $1 \%, 5 \%$, and $10 \%$ levels, respectively. 
TABLE 13

Sensitivity to Sample Period

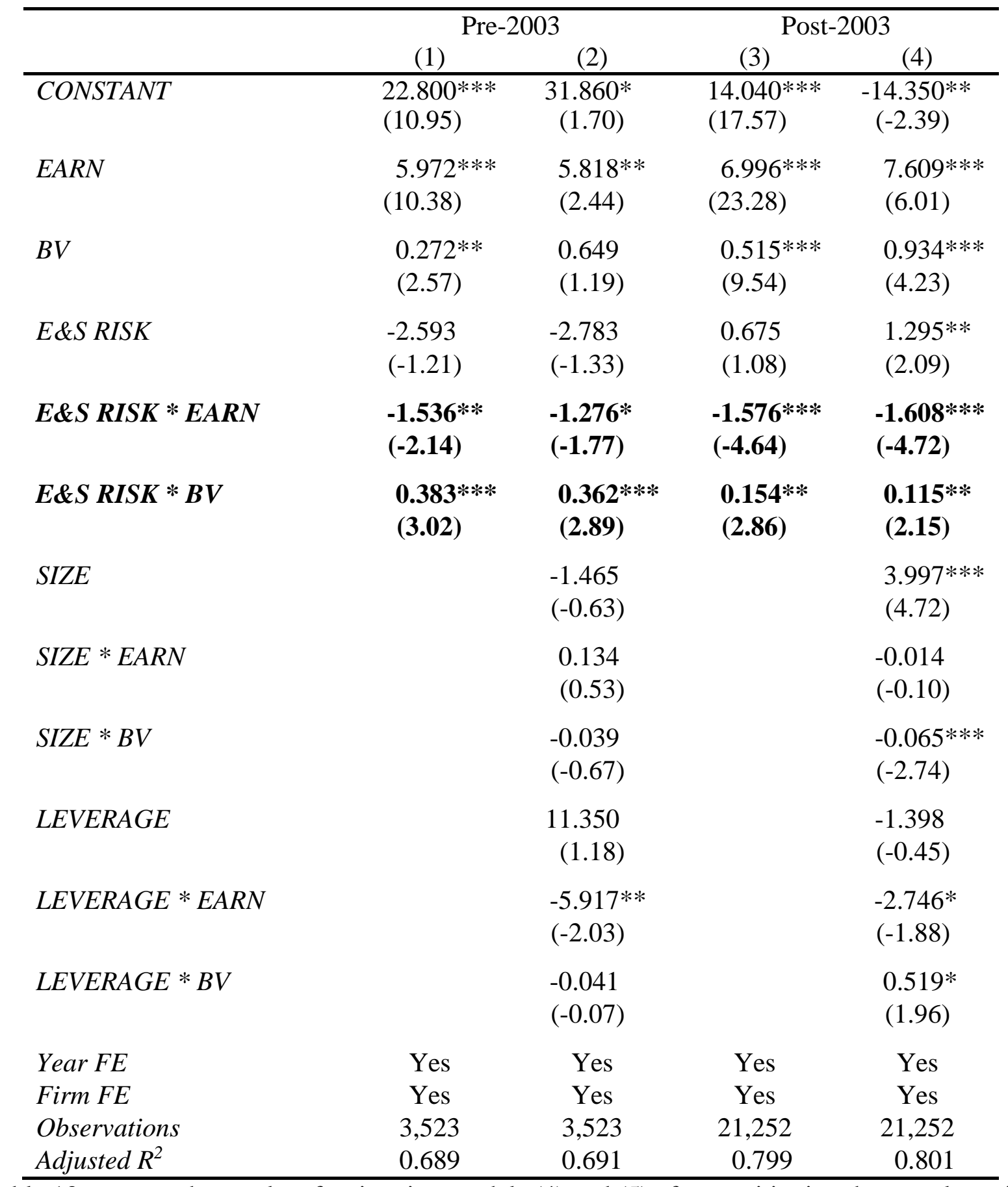

Table 13 presents the results of estimating models (4) and (5) after partitioning the sample period at 2003. Pre-2003 includes observations for the years 1995-2002. Post-2003 includes observations for the years 2003-2015. The dependent variable is the firm's share price three months after its fiscal year end $\left(P R I C E_{i, t}\right)$. Full definitions for all variables are provided in Appendix B. Standard errors are clustered by firm.

$* * *, * *, *$ denote significance at the $1 \%, 5 \%$, and $10 \%$ levels, respectively. 
TABLE 14

Examination of the Role of Asset Tangibility

with Sample Partitioned without Regard for Industry

\begin{tabular}{|c|c|c|c|c|}
\hline & $\begin{array}{c}(1) \\
\text { Low } \\
\text { Tangibility } \\
\end{array}$ & $\begin{array}{c}(2) \\
\text { High } \\
\text { Tangibility }\end{array}$ & $\begin{array}{c}(3) \\
\text { Low } \\
\text { Tangibility }\end{array}$ & $\begin{array}{c}(4) \\
\text { High } \\
\text { Tangibility } \\
\end{array}$ \\
\hline CONSTANT & $\begin{array}{c}15.170^{* * *} \\
(7.59)\end{array}$ & $\begin{array}{c}11.620^{* * * *} \\
(5.94)\end{array}$ & $\begin{array}{l}9.343 \\
(0.93)\end{array}$ & $\begin{array}{c}-7.780 \\
(-0.76)\end{array}$ \\
\hline EARN & $\begin{array}{l}7.988^{* * *} \\
(17.01)\end{array}$ & $\begin{array}{l}7.138^{* * * *} \\
(14.44)\end{array}$ & $\begin{array}{l}8.211^{* * * *} \\
(3.97)\end{array}$ & $\begin{array}{l}8.528 * * * \\
(4.39)\end{array}$ \\
\hline$B V$ & $\begin{array}{l}0.551^{* * *} \\
(6.66)\end{array}$ & $\begin{array}{l}0.555^{* * * *} \\
(5.58)\end{array}$ & $\begin{array}{l}0.569 \\
(1.44)\end{array}$ & $\begin{array}{l}0.526 \\
(1.56)\end{array}$ \\
\hline$E \& S R I S K$ & $\begin{array}{l}1.603 \\
(1.48)\end{array}$ & $\begin{array}{l}0.504 \\
(0.51)\end{array}$ & $\begin{array}{l}1.698 \\
(1.59)\end{array}$ & $\begin{array}{l}0.745 \\
(0.79)\end{array}$ \\
\hline$E \& S R I S K * E A R N$ & $\begin{array}{l}-2.084 * * * \\
(-3.60)\end{array}$ & $\begin{array}{l}-1.820 \text { **** } \\
(-3.33)\end{array}$ & $\begin{array}{l}-2.093 * * * \\
(-3.68)\end{array}$ & $\begin{array}{l}-1.903 * * * \\
(-3.56)\end{array}$ \\
\hline$E \& S R I S K * B V$ & $\begin{array}{l}0.142 \\
(1.55)\end{array}$ & $\begin{array}{l}0.207 * * * \\
(2.30)\end{array}$ & $\begin{array}{l}\mathbf{0 . 1 3 9} \\
(1.56)\end{array}$ & $\begin{array}{l}0.197^{* * *} \\
(2.26)\end{array}$ \\
\hline SIZE & & & $\begin{array}{l}0.905 \\
(0.65)\end{array}$ & $\begin{array}{l}3.080^{*} \\
(1.91)\end{array}$ \\
\hline$S I Z E * E A R N$ & & & $\begin{array}{l}0.053 \\
(0.23)\end{array}$ & $\begin{array}{l}-0.067 \\
(-0.28)\end{array}$ \\
\hline$S I Z E * B V$ & & & $\begin{array}{l}-0.010 \\
(-0.23)\end{array}$ & $\begin{array}{l}-0.010 \\
(-0.23)\end{array}$ \\
\hline LEVERAGE & & & $\begin{array}{l}-0.856 \\
(-0.16)\end{array}$ & $\begin{array}{l}2.880 \\
(0.46)\end{array}$ \\
\hline LEVERAGE * EARN & & & $\begin{array}{l}-3.319 \\
(-1.46)\end{array}$ & $\begin{array}{l}-5.182 * * \\
(-2.03)\end{array}$ \\
\hline LEVERAGE *BV & & & $\begin{array}{l}0.168 \\
(0.41)\end{array}$ & $\begin{array}{l}0.260 \\
(0.58)\end{array}$ \\
\hline Year FE & Yes & Yes & Yes & Yes \\
\hline Firm FE & Yes & Yes & Yes & Yes \\
\hline Observations & 9,541 & 9,529 & 9,541 & 9,529 \\
\hline Adjusted $R^{2}$ & 0.768 & 0.751 & 0.769 & 0.753 \\
\hline
\end{tabular}

Table 14 presents the results of estimating models (4) and (5) after partitioning the sample at the annual median asset tangibility (TANGIBILITY). TANGIBILITY is calculated as current assets plus net property, plant and equipment divided by total assets at the end of year $t$. The dependent variable is the firm's share price three months after its fiscal year end $\left(P R I C E_{i, t}\right)$. Full definitions for all variables are provided in Appendix B. Standard errors are clustered by firm. $* * *, * *, *$ denote significance at the $1 \%, 5 \%$, and $10 \%$ levels, respectively. 
FIGURE 1

Incremental Value Relevance of Earnings and Book Value

\section{Panel A: Incremental Value Relevance of Earnings}

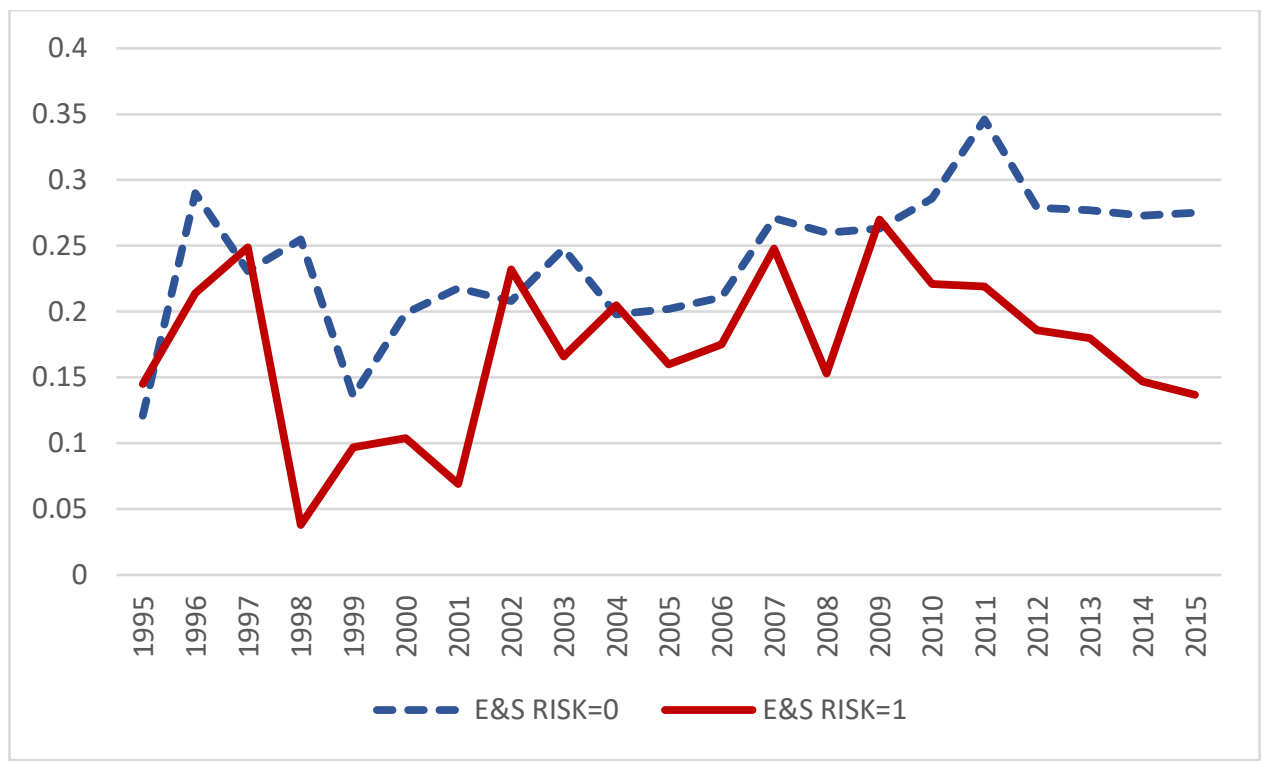

Panel B: Incremental Value Relevance of Book Value

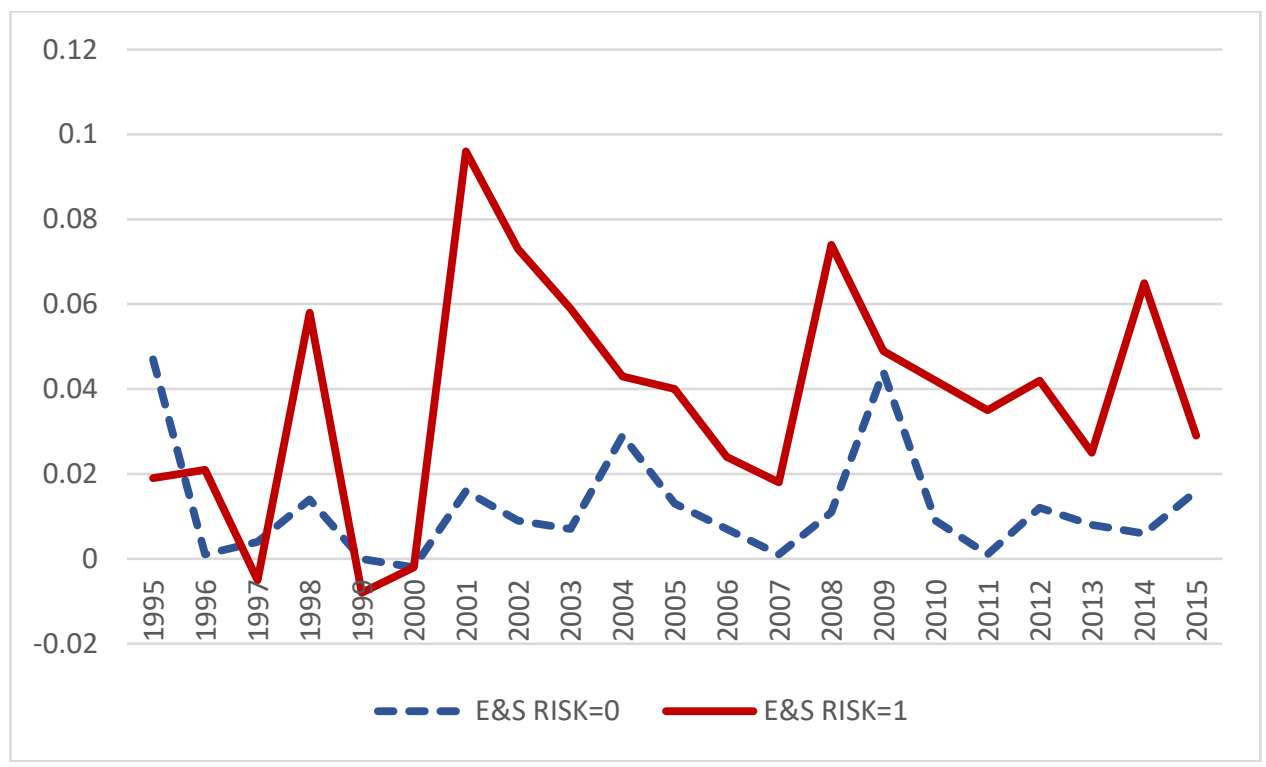

Panel A presents a comparison of the incremental value relevance of earnings between firms with E\&S risk and firms without E\&S risk. Panel B presents a comparison of the incremental value relevance of book value between firms with E\&S risk and firms without E\&S risk. See Table 4 for the annual $\mathrm{R}^{2}$ decomposition analysis used to create Figure 1. 